\title{
الموازين في اللغة العربية... تكامُل أم تعارُض؟
}

\author{
عبيد بن أحمد بن عبيد المالكي

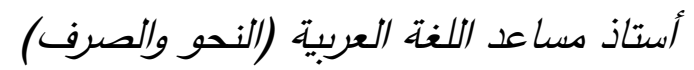 \\ جامعة الباحة - اللغة العربية \\ الآداب والثعلوم الإنسانية
}

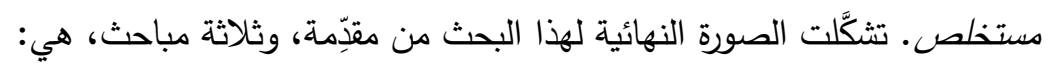

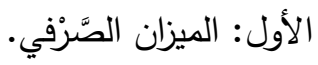

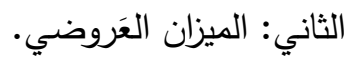
الثالث: الميزان التصغيري.

ثم الخاتمة، وفهرسي المصادر والمراجح، والموضوعات. هذا وقد سعَى البحثُ إلى استعراض تلك الموازين؛ ليجيبَ عن سؤال مشكلته، التي تكمُن في صورة العلاقة بينهما،

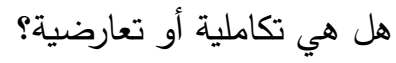

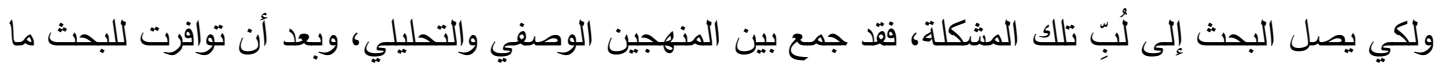

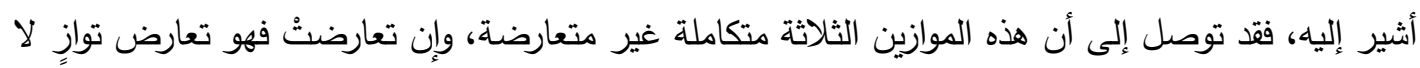
تداخل؛ لأن لكل وزن منها طريقتَه وغايته، هذا والله الموفِّ. الكلمات المفتاحية: الميزان - العربية - الصرف - العروض - التصغير - التكامل - التعارض.

والعروضي، والتصغيري، واثشتركت الموازين الثلاثة في اشتقاقها من (فَعَ))، وقد تتفق هذئه الموازين وقد تختلف، ولذا تتبلور مشكلة البحث في الإجابة عن السؤال الآتي: ما العلاقة بين الموازين الثلاثة؟ وهل الاجلهابه

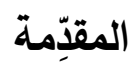

وضَع علماء اللغة العربية موازينَ عِدةً في علوم مختلفة، لكل ميزان منها غرض يخدم العلم الذي وضع

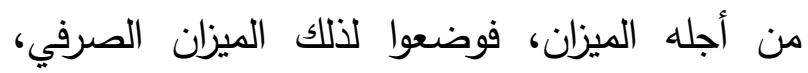


استعراض ماهية تلك الموازين، ودراسة وجوه الاتفاق بينها، ووجوه الاختلاف أيضًا، للوصول للإجابة الرئيسة عنه، وهي العلاقة بينها هل هي متكاملة أو الوفي متعارضة؟ وللوصول أيضًا لإجابة مقنعة في هذا لئها السياق، فقد جمع البحث بين المنهجين الوصفي والتحليلي، ومن هنا جاء عنوانه: (الموازين في اللغة (العربية.... تكامل أم تعارض؟) لينقسم البحث إلى مقدمة، وثلاثة مباحث: تحدثت في المبحث الأول: عن الميزان الصرفي، وتهاته وفي المبحث الثاني: عن الميزان العروضي، وفي المبحث الثالث: عن الميزان التصغيري، ثم كانت خاتمة البحث، وفيها النتائج والتوصيات، وفهرس المئن المصادر والمراجع، وفهرس الموضوعات. هذا، وأسأل الله التوفيقَ والسداد في تقديم ما يُّيد ويتفع دارسي العربية ومحبيها، إنه نعم الموفق والمعين.

$$
\begin{aligned}
& \text { الباحث } \\
& \text { المبحث الأول } \\
& \text { الميزان الصَّرفي الأي }
\end{aligned}
$$

الميزان الصرفي قالب وضَعهاه العلماء لمعرفة أحوال

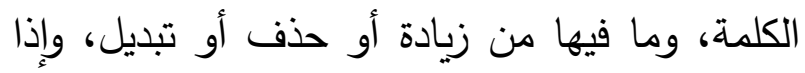
نظرنا لتعريف العلماء للوزن الصرفي لم نجد تعريفًا دقيقًا عندهم، فقد اهتموا ببيان كيفية الوزن دون وضع تعريف معين يوضح حدود هذا المصطلح،

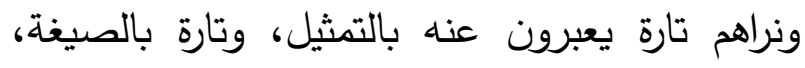

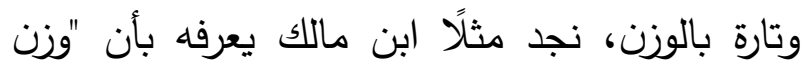
الكلمة أن تقابل أول أصولها بفاء، وثانيها بعين، وثالثها ورابعها وخامسها بلامات، ويعطى المقابل به
هي تكاملية أو تعارضية؟ هذا وقد استفدت من دراسة أ. د أحمد محمد عبد الدايم (الميزان الصرفي.. نظرة جديدة)، في فكرة المقارنة بين الموازين الثلاثة، واختلفت معها في أن دراسة أ.د أحمد محمد عبد الدايم زادت الوزن لهورين المقطعي، وهو ليس بوزن كما اصطلح عليه، وأيضًا قارنت بين الموازين الثلاثة وبعضها، وليس بين الميزان الصرفي والعروضي، والميزان الصرفي والتصغيري كما فعل. ومن دراسة د. سليمة جبار (الوزنان التصريفي والتصغيري في اللغة العربية.. رؤية في تيسير الصرف دانية العربي) واتثقت دراستي معها في أنه لا يوجد تثابه بين الوزنين الثعري والتصغيري، وربما يكون التثابه -

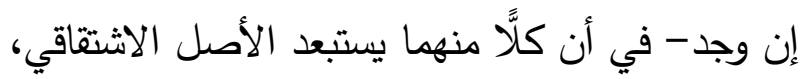

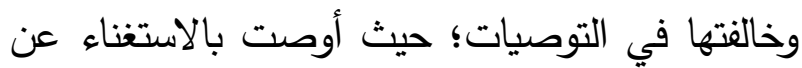
صِيَخ التصغير الثلاث، وأن يكون الوزن التصغيري هو به نفسَ الوزن التصريفي، ورأيثُ ضرورة وجود الميزان التصغيري؛ لاختلاف الغرض الذي وضع من أجله عن الغرض الذي وضع من أجله الميزان التصريفي. ودراسة الباحثة نادية رزيق (الميزان الصرفي وأثره في تطور اللغة العربية ونموها دراسة استثرائية تحليلية) التي درست العلاقة بين الديزان الصرفي والميزان العروضي، غير أن دراستها هدفت لغرض آخر وهو آثار الميزان الصرفي على تطور اللغة العربية ونموها، وبحثي عن العلاقة بين هذه الموازين وهل تتعارض أو تتكامل؟

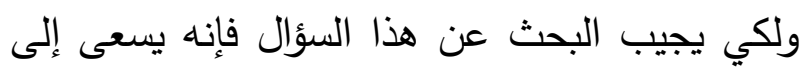


ما للمقابل من حركة وسكون ومصاحبة مزيد غير على هذا الأصل. والثاني: أنهم بنوا هذا المعيار من مخارج الحروف الثثاثة وهي: الثفتان ووسط الفم والحلق؛ فالفاء

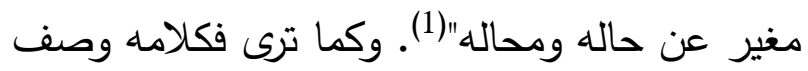
كيفية الوزن أكثر منه تعريفًا جامعًا مانعًا. شفهية، والعين حلقية، واللام من وسط الفر"(4). ويوضِّح ابن عصفور الغرض من اختيار لفظ (فَعَل) دون غيره للميزان بقوله: " فإن قيل: فلحَ كَنَوا عن الأُصول بالفاء والعين واللام:؟ فالجواب أنَّ الذي فئولي حَملهم على ذلك أنَّ حروف الذ"فعل" أُصول، فجعلوها لذلك في مقابلة الأُصول. فإن قيل: فهلَّا كنَوا عن الأُصول بغير ذلك من فن

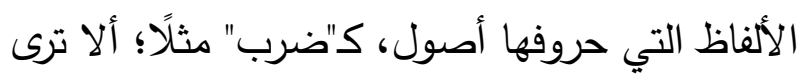
أنَّ الضاد والراء والباء أُصول؟ فالجواب أنهم لمَّا

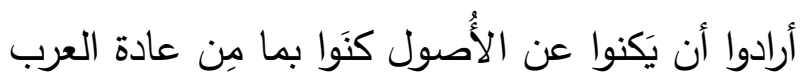

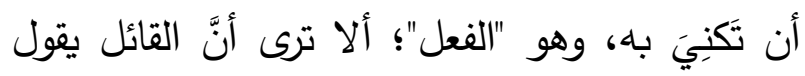

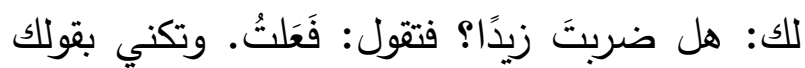

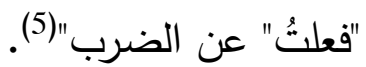
كما أن هناك سببًا آخر ، وهو أن حروف (فَعَل) كلها صحيحة ليس فيها حرف معتل يتعرض للحذف أو أو أن

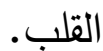
ولنا هنا وقفة؛ فإن العلماء حين اختاروا لفظ (فَعَل) لم يكن مقصودًا لذاته، وإنما هو القالب الذي رأوا أنه يعبر إنداء

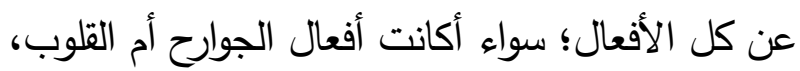

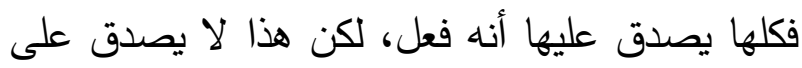

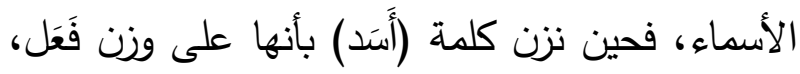
فليس ثمة مناسبة بينهما، لكن يمكن أن يُعتذَر عن هذا

ويقول ناظر الجيش: "لما راموا وزن الكلمة قابلوا أوَّلَ أصولها بفاء، وثانيها بعين، وثالثها ورابعها وخامسها لهائا بلامات؛ فلهذه المقابلة يُسمَّى أول الأصول فاءًً، وثانيها عينًا، وثالثها لامًا، وكذا رابعها وخامسها إن كانا، وأشار بقوله: مسوَّى بينهما، إلى أنه يسوى بين

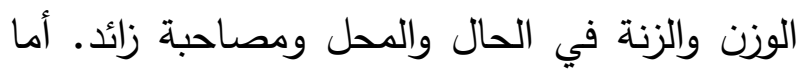
الحال: فالمراد به الحركة والسكون فيعطى المقابل به

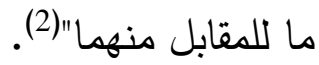
وقد اختار العلماء أن يكون الوزن ثلاثيَّا؛ لأن الثلاثي

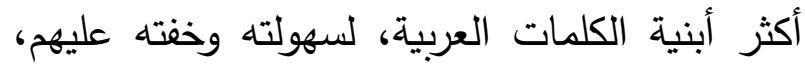
يقول ابن يعيش: "فإن قيل: ولِم كان الميزان ثلاثيًّا،

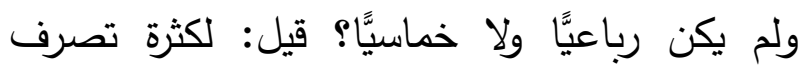
الثلاثي، ولأنه لو جعل رباعيًّا أو خماسيًّا لم يمكن وزن الثلاثي باه، إلا بإسقاط شيء منها، فجعل ثلاثنيَّا،

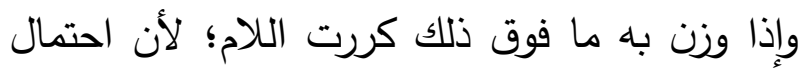

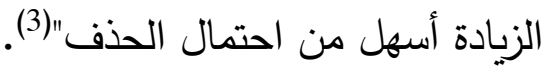
وقد اختاروا لله مادة (فعل) لأمور عدة كما يقول العكبري: "وإنما قابلوا الحروف الأصول بالفاء والعين

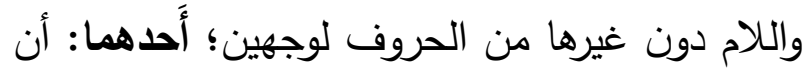
التصريف في الأصل من أحكام الأفعال، فلما أرادوا اعتبارها جعلوا المعيار لذلك حروف الفعل تتبيهًا

(1) ابن مالك، محمد، إيجاز التعريف في علم التصريف، (84-85).

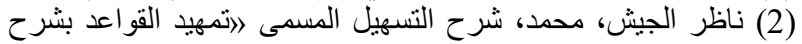

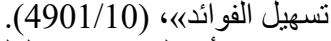
(3) ابن يعيش، أبو البقاء، شرح الملوكي في التصريف، (294). 
قولك: الهمزة من أحمد زائدة، وسائر حروفه أصول،

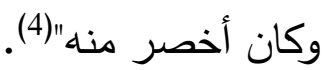
وزاد ابن عقيل أيضًا بيان محل الأصل ويعني به

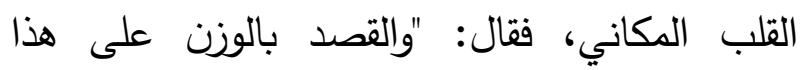
الوجه: تعريف الأصلي من الزائد، في الأكثر، بالونئ باختصار ، وبيان محل الأصل"(5). وذكر الثيخ خالد الأزهري ثمانية أمور تستفاد من الاصل الوزن، حيث يقول: "وفائدة الوزن بيان أحوال أبنية الكلم

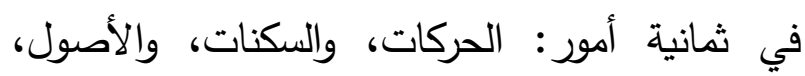
والزوائد، والتقديم، والتأخير ، والحذف، وعدمه" (6) فئ.

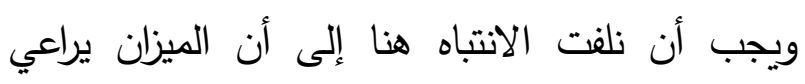
الأصل المفترض، حتى لو أدى لتجاور حروف قد لا لا لاني تتجاور في كلام العرب؛ لأنه ليس موضوعًا لإدخال كلمات جديدة في العربية، وإنما لتمثيل الموجود؛ ليعلم

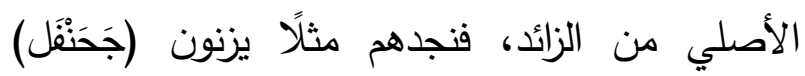
بفَعَنَلَ، مع أن العرب لا تتطق النون الساكنة قبل اللام

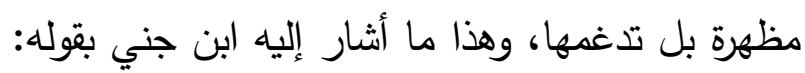
"وذلك كقولهم في التمثيل من الفعل في حبنطى:

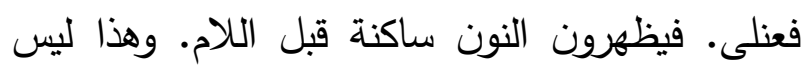

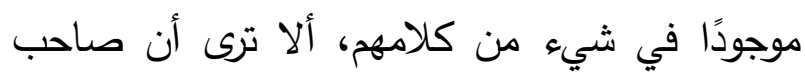

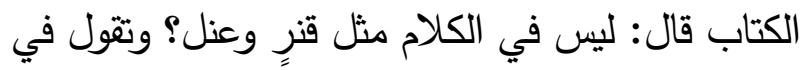

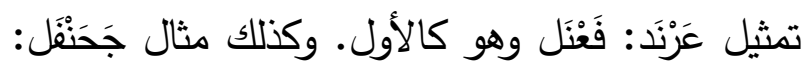

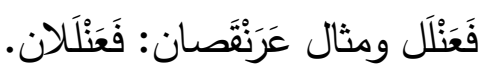

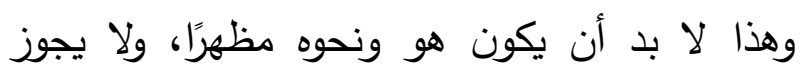

(4) ابن عصفور، أبو الحسن، مصدر سابق، (206).

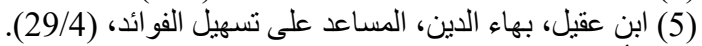
(6) الأزهري، خالد، التصريح بمضمون التوضيح، (321/5).
بما قاله السيوطي: "اصطلح النحويون على أن يزنوا بلفظ الفعل، لمَّا كان الفعل يعبر به عن كل فعل،

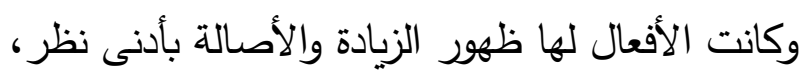
ثم حملوا الأسماء عليها في أن وزنوها بالفعل" (1). وتوضح د. خديجة الحديثي سبب تسمية (فعل) وما

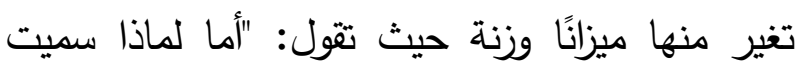

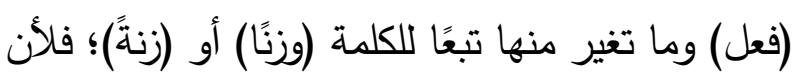

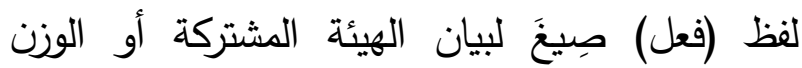

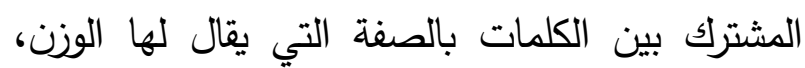

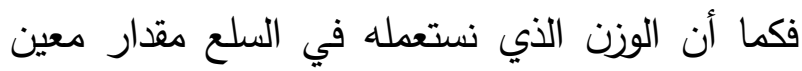

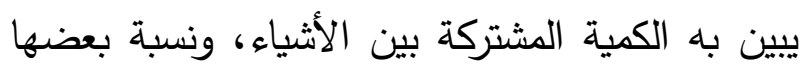

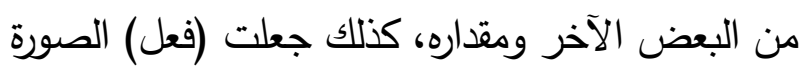
أو الهيئة التي تقاس بها هيئة كلمة ومقدارها بالنسبة إلى كلمة أخرى... فلما كان المراد من صوغ (فعل)

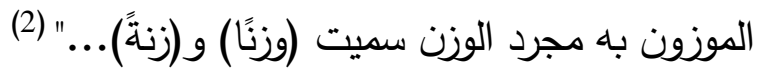

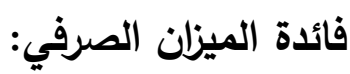
وفائدة الميزان معرفة الأصلي من الزائد على طريق المرفيق

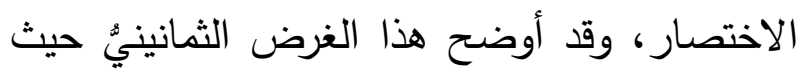

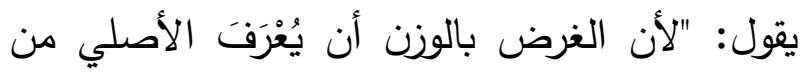

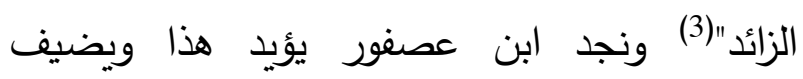
الاختصار حيث قال: "فإن قيل: وما الفائدة في وزن الكلمة بالفعل؟ فالجواب أن المراد بذلك الإعلام بمعرفة الزائد من الأصلي على طريق الاختصار ، ألا ترى أنك إذا وزنت أحمد بِ"أفعل" أغنى ذلك عن عن الاهي (1) السيوطي، جلال الدين، همع الهوامع في شرح جمع الجوامع، (2) الحديثي، خديجة، أبنية الصرف في كتاب سييويه، (81/38)، (199). (3) الثمانيني، عمر ، شرح التصريف، الثيف، (191). 
وفعلّ، وحرفت. فالحرف لا يوزن؛ لأنّ الغرض بالوزن

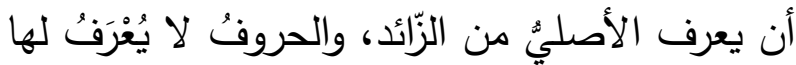

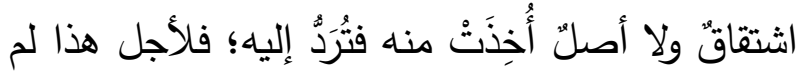
توزن. ألفاتُها كلُها أصولٌ كألف "ما" و "لا" و"إلّا "اله و "حتّى" و "أمّا" وما أشبه ذلك، ولا يُحْكَُ على ألفاتِها بالانقلاب عن ياءٍ ولا واوٍ ولا همزةٍ، ولا بأنّها زائدةٌ

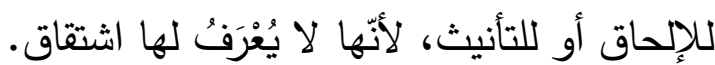

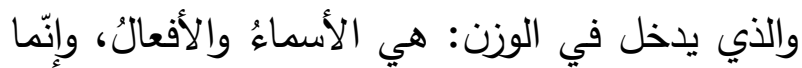
دخلتا في الوزن؛ لأنّّه يعرف اشتقاقهما وأصولهما

والزبادة عليهما"(3).

ويستدل ابن عصفور على أن الحرف لا يدخله التصريف بأن "ما" و"لا" لو كانت الألف منقلبة فيهما عن واو أو ياء لظهرتا لسكونهما، كما استبعد ما عجمته شخصية، وأسماء الأصوات، حيث يقول: "اعلم أن التصريف لا يدخل في أربعة أثياء. وهي: الأسماء الأعجمية التي عجمتها شخصية، ك"إسماعيل" ونحوه؛ لأنها نقلت من لغة قوم ليس الس الئ حكمها كحكم هذه اللغة. والأصوات ك"غاق" ونحوه؛ لأنها حكاية ما يصوت به، وليس لها أصل معلوم. والحروف، وما شُبّهّه بها من الأسماء المتوغلة في البناء، نحو "من" و"ما"؛ لأنها لافتقارها بمنزلة جزء الاعياه

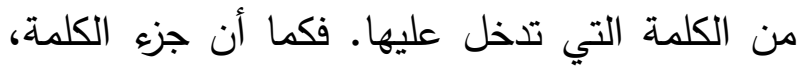
الذي هو حرف الهجاء، لا يدخله تصريف فكذلك ما

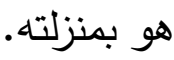
وقد جاءت بعض الكلمات المبنية مشتقَّة، نحو "قَظُّ"؛
إدغام النون في اللام في هذه الأماكن؛ لأنه لو فعل ذلك لفسد الغرض. وبطل المراد المعتمد... وبهذا تعلم أن التمثيل للصناعة ليس ببناء معتمد" (1). الألفاظ الخاضعة لقانون الميزان: ليس كل الكلمات خاضعة للوزن، وإنما يوزن ما يعرف اشتقاقه؛ فالحروف لا توزن ولا الأعجمي غير لانكان

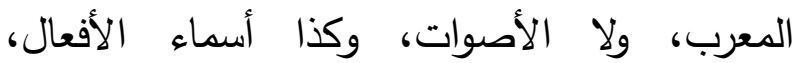
والأسماء المبنية بناء لازمًا، وإنما يوزن الأسماء المتمكنة، والأفعال؛ لأن الغرض إنما هو معرفة الأصلي من الزائد، حيث يقول ابن جني: "أول مال

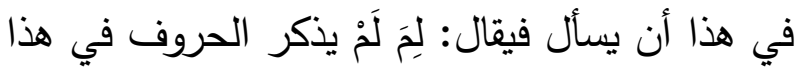

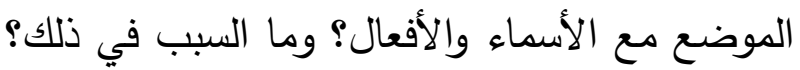
والجواب: أنه إنما قصد أن يمثل الأسماء والأفعال؛

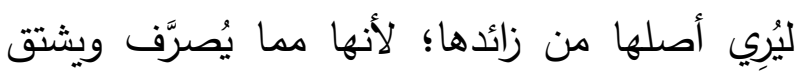
بعضها من بعض، والحروف لا يصح فيها التصريف ولا الاشتقاق؛ لأنها مجهولة الأصول،

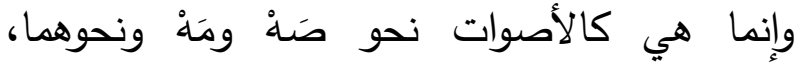
فالحروف لا تمثل بالفعل؛ لأنها لا يعرف لها

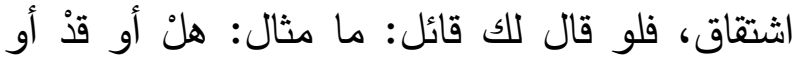
حتَّى أو هلَّا ونحو ذلك من الفعل لكانت مسألته محالًا، وكنت تقول له: إن هذا ونحوه لا يمثل؛ لأنه ليس بمشتق، إلا أن تتقلها إلى التسمية بها، فحينئذ يجوز وزنها بالفعل، فأما وهي على ما هي عليه من لإن إنى

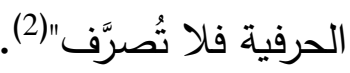
ويقول الثمانيني: "الكلامُ كلُه ثناثة أقسام: اسمٌ، 
فَعُولُّ وضَارِبٌ: فَاعِلٌ .. فِيوازنون الأصول بالأصولِ

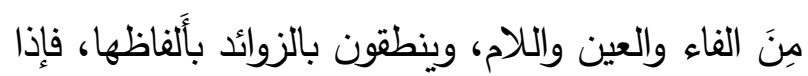
قالوا: فاء هذا الحرف واو أو ياء؛ فإنما يعنون أن أول ولئل حرف منه أصلي واو أو ياء، وكذلك إذا قالوا: عينه

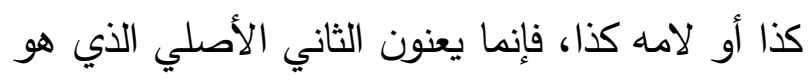

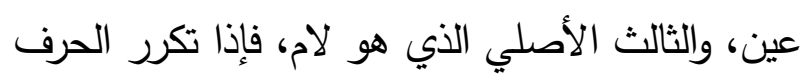
الأصلي بعد تمام الثلاثة كرروا اللام"(2).

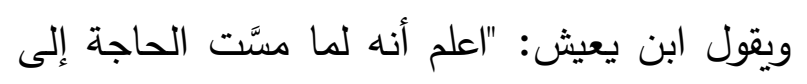

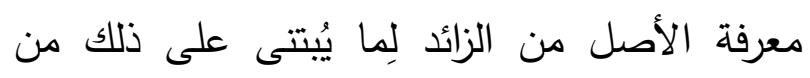

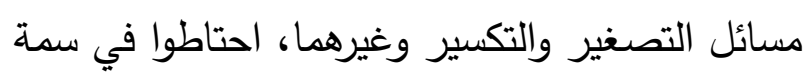

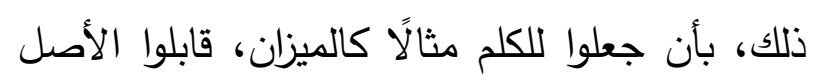

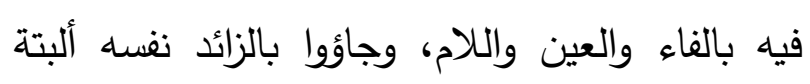
محكيًا. ويكون نظم الحركات والسكون في المثال

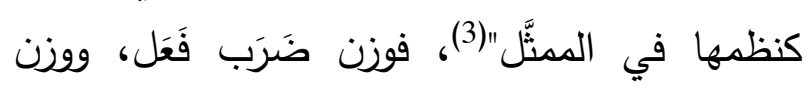

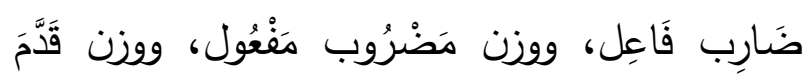

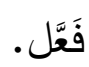

في حين يرى الكوفيون أن الأصول ثلاثة فقط، فما

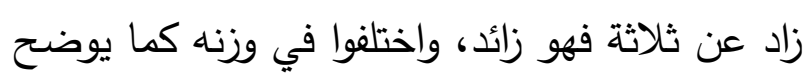
ذلك أبو حيَّان بقوله: "وقد اصطلح النحاة على أن وان

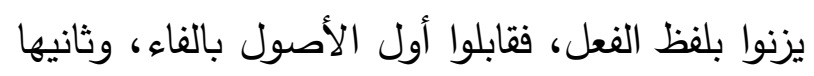

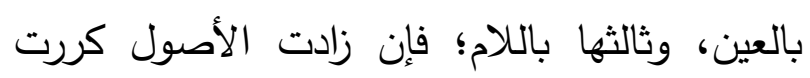
اللام عند البصريين، ومذهب الكوفيين أن نهاية الأصول ثلاثة، وما زاد على الثلاثة حكموا بزيادتها،

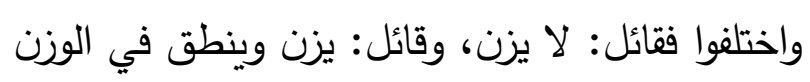

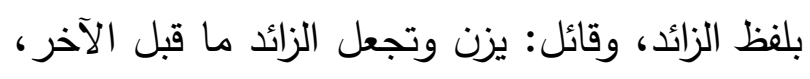

لأنها من "قططتُ" أي: قطعت؛ لأن قولك: "ما فعلته

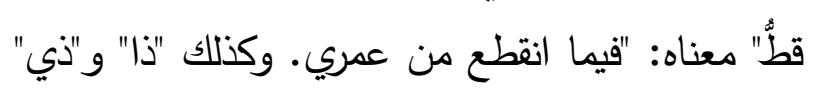

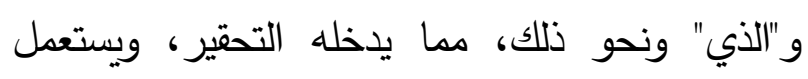
استعمال المتصرف، وليس ذلك بالكثير، وكلما كان الاسم من شبه الحرف أقرب كان من التصريف أبعد. ومما يدلك، على أن الحرف لا يدخله تصريف،

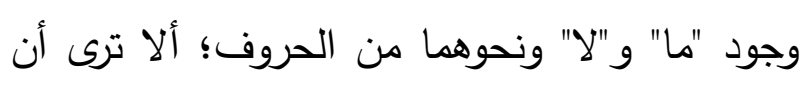

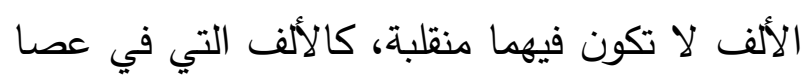

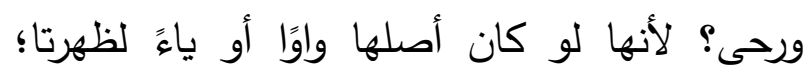

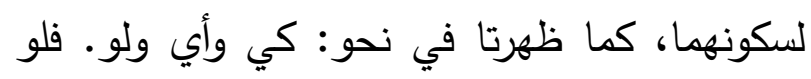

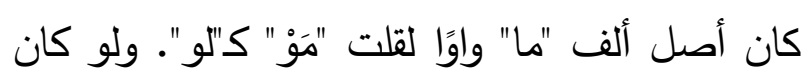
ياء لقلت "مَتئ" ك"كي"؛ لأن حرف العلة إنما كان يقلب، لو كان متحركًا وقبله مفتوح" (1). وهو يعني بالتصريف هنا الميزان وبيان المزيد والأصلي والمنقلب عن غيره.

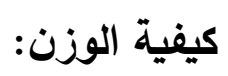

اختلف العلماء في كيفية الوزن، فيرى جمهور

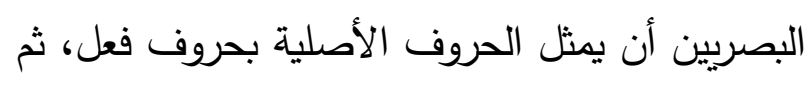

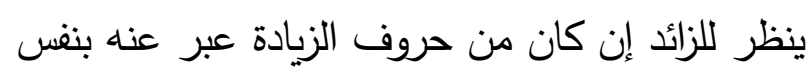

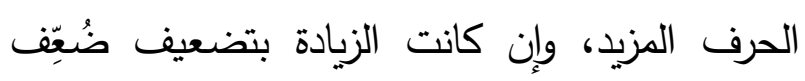

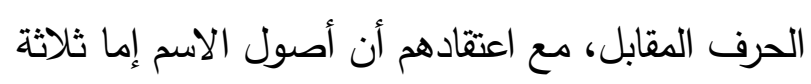
وإما أربعة وإما خمسة، وأصول الفعل إما ثلاثة وإما أربعة. يقول ابن السراج: "واعلم أن النحويين قد جعلوا

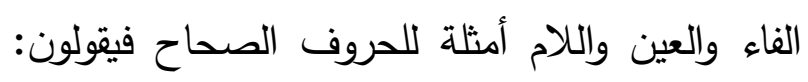

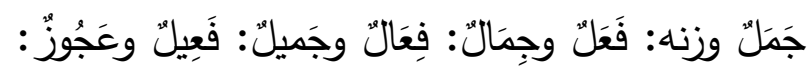


لفظت بالزائد في المثال، فتقول في كِتَاب: فِعَال،

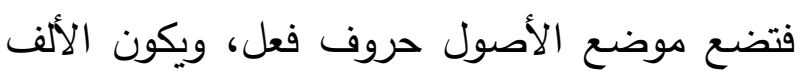

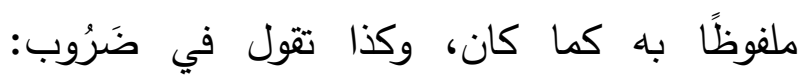

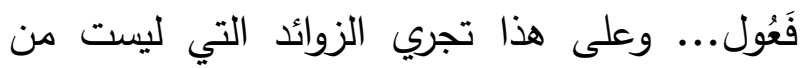
حروف التركيب، فأما ما كان من حروف التركيب،

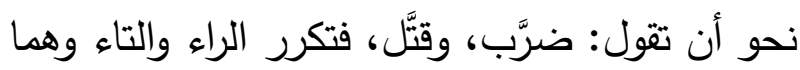
مما ركب عليه الكلمة، ففيه مذهبان: الأظهر الأكثر أن تقول: فعَّل، فتكرر في المثان فئه الحرف الذي هو بإزاء الحرف المكرر كتكرير العين مجريا لله مجرى تكرير الراء في ضرَّب.

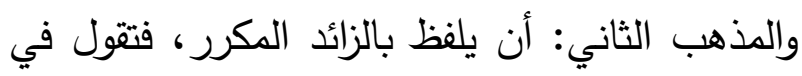

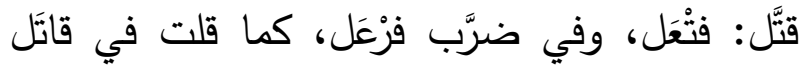
وضارَب: فاعَل، وذلك أنك قصدت وفرئ اللفظ بالزائد كما فيا هو، ولا يكون الوجه الأول في نحو: قاتلك؛ لأن الألف ليس بحرف من حروف التركيب فتكرر العين

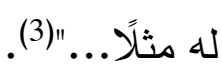
أما ما عليه الجمهور فهو الدذهب الأول الذي ذكره

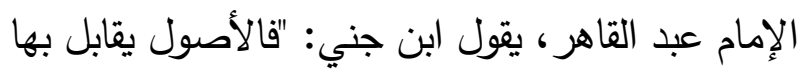
في المثال: الفاء، والعين، واللام. ويُلفَظ بالزائد بعينه

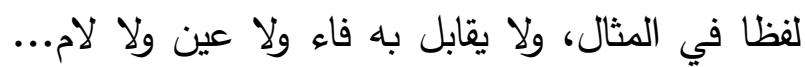

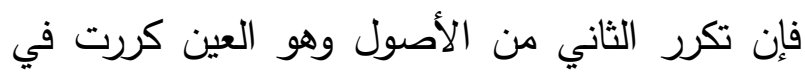

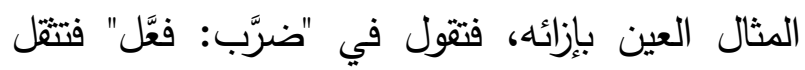

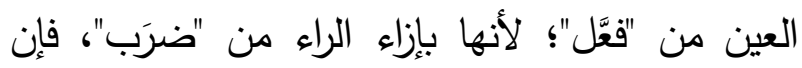

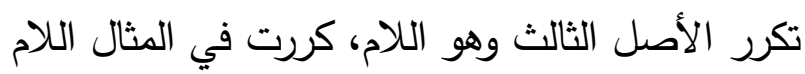

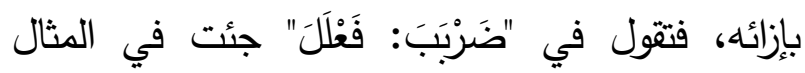
(3) الجرجاني، عبد القاهر، المقتصد في شرح التكملة، (1185/3-

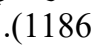

فيجعل وزن 》جعفر): فعلًا، وقائل: يزن كوزن

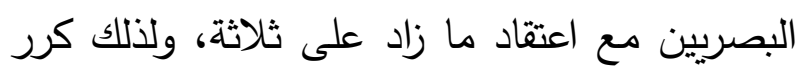

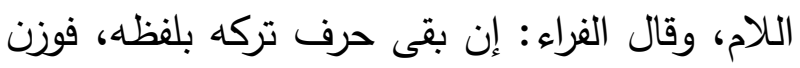

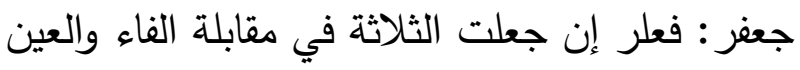
والتلام؛ وإن جعلت الثلاثة الأخيرة في مقابلتها قلت: جعف، أو في مقابلة الأولين والأخيرين قلت:

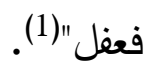

ويقول الثيخ خالد الأزهري: "والثاني: أن ما زاد على الثلاثة زائد، قاله الكوفيون، بناء على قولهم: إن منتهى الأصول ثلاثة كما تقدم عنهم، ثم اختلفوا على لثى

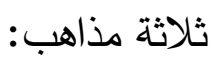
أحدها: أنه لا يوزن؛ لأنه لا يدرى كيفية الوزن. والثاني: أنه يوزن، ويقابل آخره بلفظه. والثالث: أنه يوزن ويقابل الذي قبل آخره بلفظه، وهو مبني على أن الزائد هل هو الآخر أو ما قبله فالفراء على الأول، والكسائي على الثاني. فهل "جعفر": "فعلل" كما يقول البصريون، أو "فعلر" الألئ

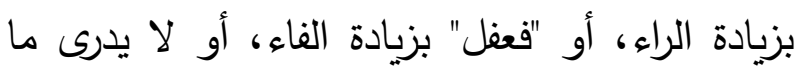
هو بـ أقوال أربعة"(2). بينما يرى جمهور البصريين أن يعبر عن الزائد بلفظه في حروف الميزان إن كان من حروف الزيادة العشرة (سألتمونيها)، فإن كانت زيادة تكرير كررنا

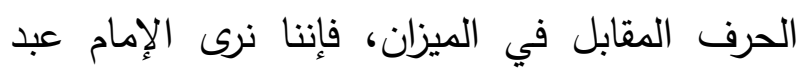
القاهر يخالف هذا حيث يقول: "... وإذا مثلت الكلمة

$$
\text { (1) الأندلي، أبو حيان، ارتثاف الضرب من لسان العرب، (28/1- }
$$


أخرى، فنراهم يعتدون بالقلب المكاني وبالحذف، فوزن

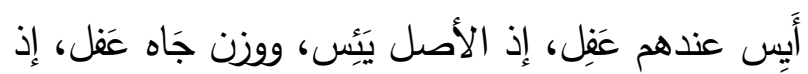

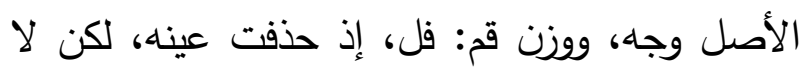

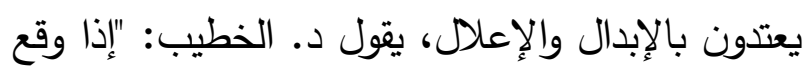

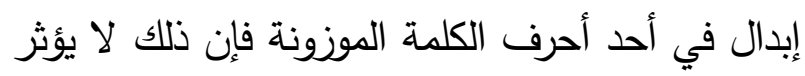
في الميزان، ولا يغير من صورته، ومن أمثلة ذلك:

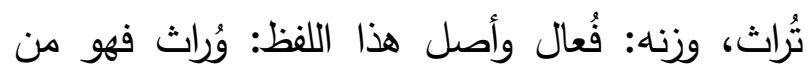
ورث، فأبدل من الواو تاء، ولكن الوزن لم يتغير فيه

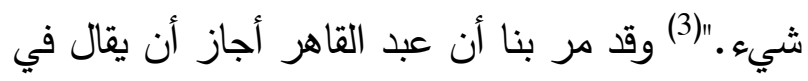

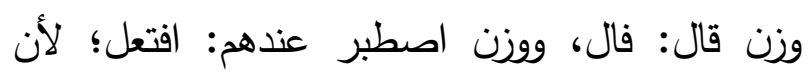

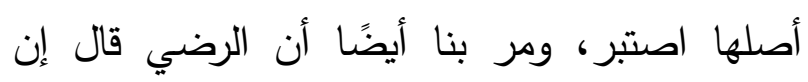

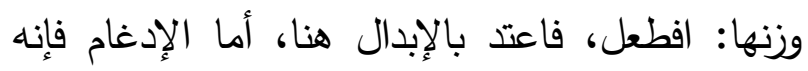

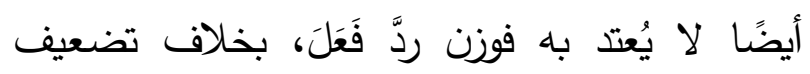
الحرف فإنه يعتد به فوزن كَلَّمَ فَعَّلَ.

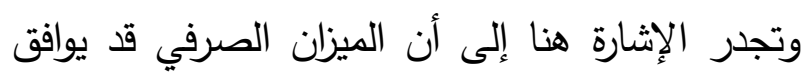

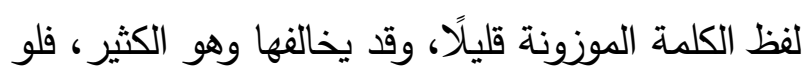

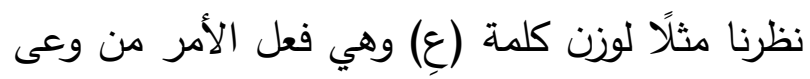

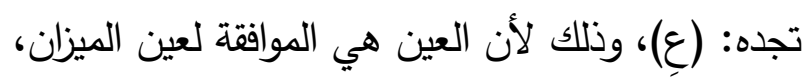
وقد ذكرت أن الحذف يعتد به في الميزان عندهم، وكذا وزن كلمة فَعَلَ: فهي فَعَلَ أيضًا. ويسوقنا الحديث في هذا السياق للتفريق بين الصيغة فئة

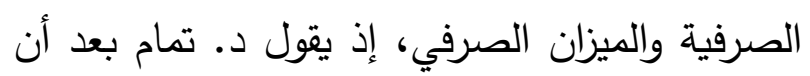
ضرب مثالًا لإيضاح الفرق بينهما:

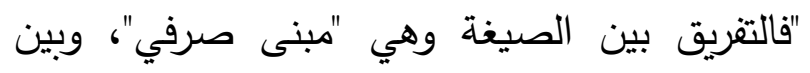

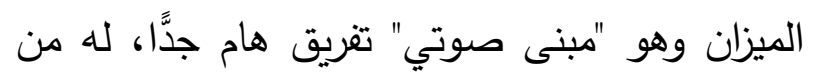

(3) الخطيب، عبد اللطيف، المستقصى في علم التصريف (64/1).
بلامين، لما كان في ضَرْبَبَ باءان، فإن تكرر الأصلان كلاهما، كررت في المثال العين والتلام

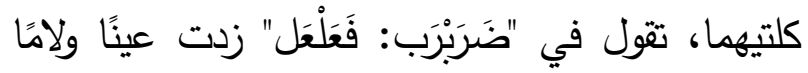

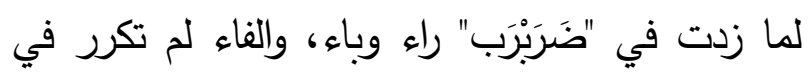
كلام العرب إلا في حرف واحد، وهو "مَزََِِْي...." (1).

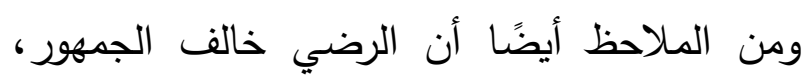
وأجاز أن يعبر عن لفظ البدل بمثله، فيقال في وزن التطن اضطرب افطعل، حيث يقول: "قوله "ويعبر عن الزائد بلفظه": أي يورد في الوزن الحرفُ الزائد بعينه

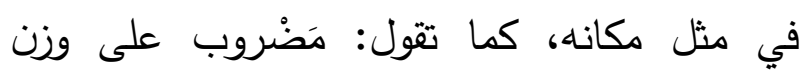
مَفْعُول. قوله " إلا المبدل من تاء الافتعال " يعني تعني

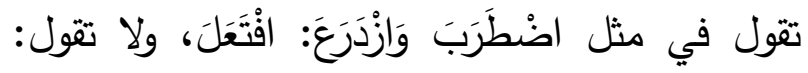

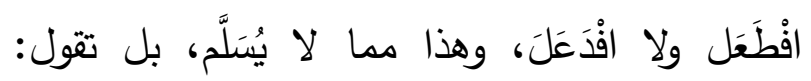

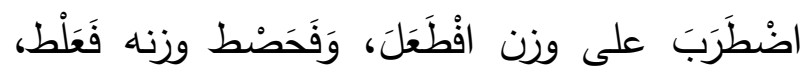

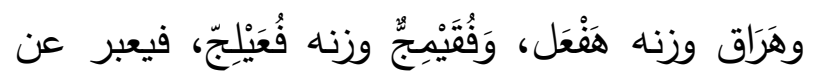

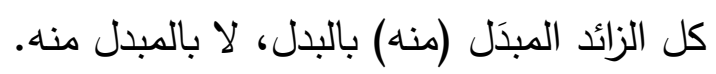

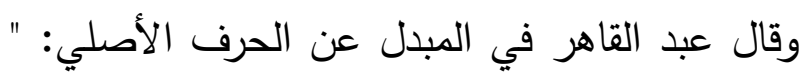
يجوز أن يعبر عنه بالبدل، فيقال في قال: إنه على على الاهي: وزن فال. انتهى" (2).

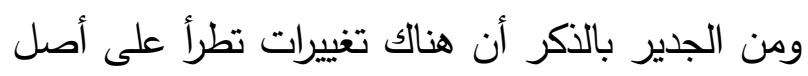
الكلمة من تغيير لحرف بدل حرف، وهو ما يسمى بانى

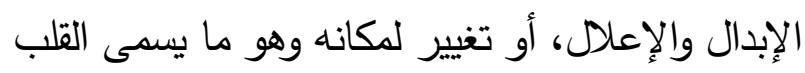

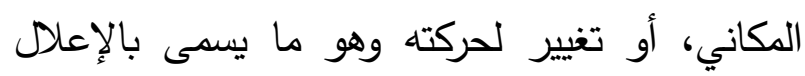
بالنقل، وهذه التغييرات التي تدخل على أصل الكلمة

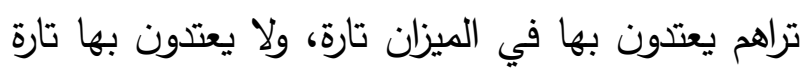

(1) ابن جني، المنصف، (12/1). (2) الإسنر اباذي، الرضي، شرح شافية ابن الحاجب، (18/1). 
الأهمية ما يكون منها للتغريق بين علمي الصرف الميزان العروضي والميزان التصغيري، ودراسة العلاقة بينها. ونشير هنا إلى أن أصول الكلمة ليست وليت والأصوات.

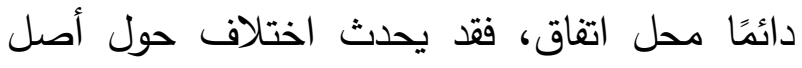

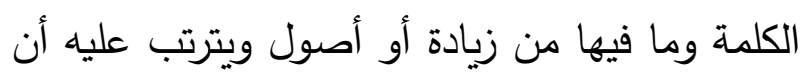

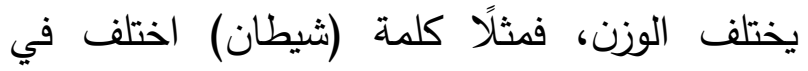
أصلها هل هي من شيط أو من شطن؟ فيكون أصولها الثين والياء والطاء، أو الثين والطاء

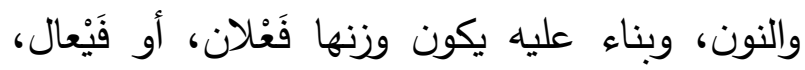

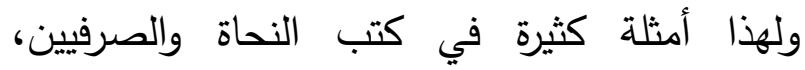
والاختلاف فيها راجع للاختلاف في أصول الكلمة

الموزونة.

وبعد معرفة ما سبق نتوقف لنسأل: هل يحقق الميزان

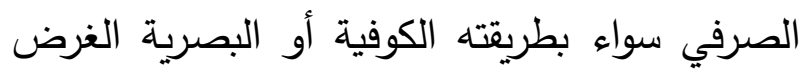
الذي أنشئ من أجله؟ وللإجابة عن هذا السؤال ننظر للغرض الذي لني وضع

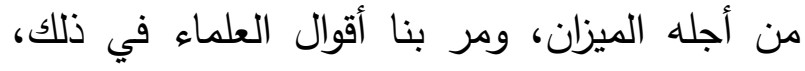
والذي يدور حول معرفة الزائد من الأصلي في لئي

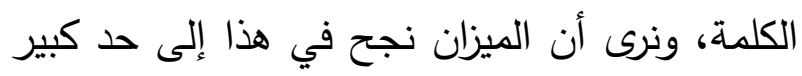

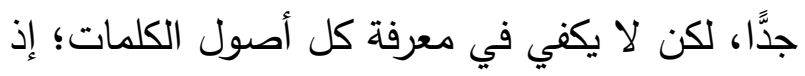
رأينا اختلافهم حول وزن كلمة شيطان مثثلا، وغيرها كثير، ومن هنا يمكن القول: إن الميزان الصرفي أفاد

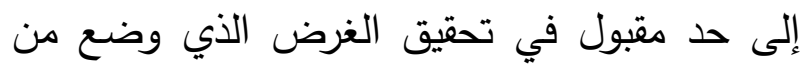
أجله، ودل القارئ أو السامع على معرفة الأصلي من الزائد في الكلمة الذي سينبني عليه أحكام أخرى الته

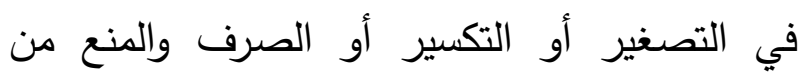
الصرف وغيرها.

وقد يتقق هيكل الصيغة في صورته مع هيكل

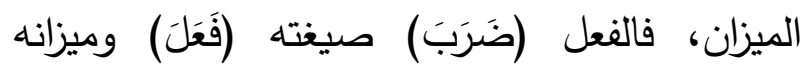
(فَعَلَ) أيضًا، ولكنهما قد يختلفان كما رأينا في فعل

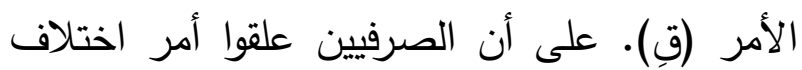

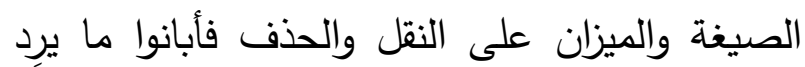

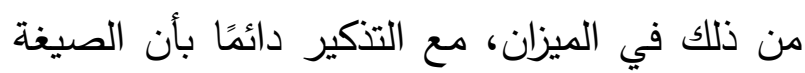

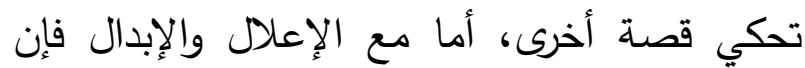
علماء الصرف لم يحفلوا بالفروق بين شكل الصيغة الصعاد

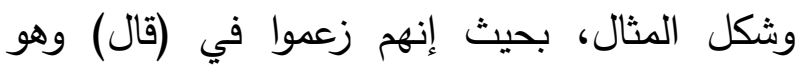
ينتمي لصيغة (فَعَل) أنه على وزن (فَعَلَ) أيضًا، وليس على وزن (فَالَ)، وما إصرار علماء الصرف لهاء

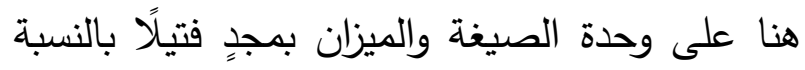

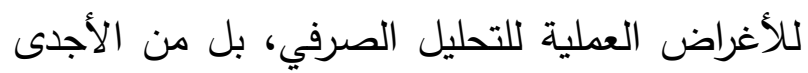
أن نلقي على عاتق الصيغة بيان المبنى الصرفي

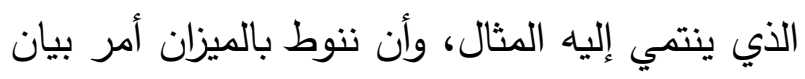

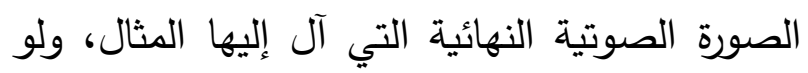
اتحد هذا وذاك لغاب من تحليلنا أحد هذين الأمرين الهامين، ومن هنا أقترح أن التحليل الصرفي كما

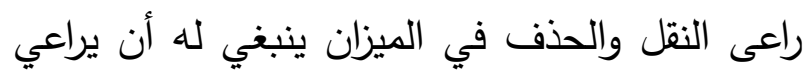
الإعلال والإبدال أيضًا..." (1). ويتصل بالميزان الصرفي معرفة أبواب حروف الزيادة والإعلال، وليس غرضي في هذا البحث بيانها، وإنما بيان فلسفة الميزان الصرفي للمقارنة بينه وبين (1) حسان، تمام، اللغة العربية معناها ومبناها (145). 
أجل معرفة الزائد والأصلي، وما طرأ على اللفظ

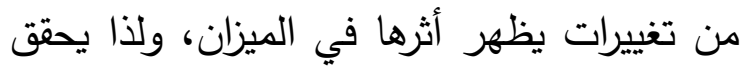

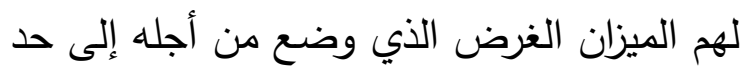

كبير -

\section{المبحث الثاني}

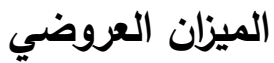

مثلما وضع الصرفيون ميزانًا للصرف؛ لبيان حروف الكلمة وما فيها من أصلي أو زائد أو مبدل من غيره، فقد وضع العروضيون ميزانًا للشعر لـعرفة نوع البحر وما يجوز فيه من زحافات وعلل أو لا يجوز ،

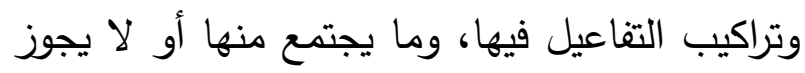
اجتماعه، وإن كان الصرفي يتعامل مع الكلمات باعتبار كل كلمة وحدة مستقلة وينظر لحروفها، فإن العروضي يتعامل مع مقاطع لا مع كل كلمة وحدها، مثلما يوضح ذلك د. أحمد عبد الدايم بقوله: "العَروضيُّ غير الصَّرفي في تعامله مع وحدات

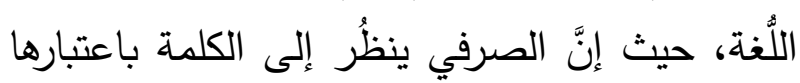
وحدةً مستقلة لا عَلاقةََ لها بما قبْلها أو بما بعدَها. أمَّا العَروضيٌّ، فإنه يقطِّع الجملة (البيت الثعري) مقاطعَ توازي أوزانه، ولا عِبرة للكلمة عندَه، وإنما قد يكون مقطعه مكونًا مِن جزأين مِن كلمتين مختلفتين، أو مكونًا مِن كلمة وجزء مِن كلمة أخرى" (1). كما لا يُعنى العروضيون بالحروف الأصلية أو مين الزائدة أو المبدلة، فالعروضي يهتم بالحركة والسكون

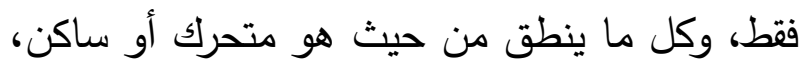

قراءة في مضامين النصوص: تبين لنا من خلال استعراض النصوص السابقة ما يلي:

1- ليس للميزان الصرفي تعريف محدد للمصطلح، وإنما اهتم الصرفيون أكثر بتوضيح

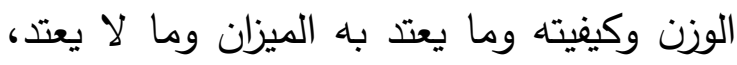

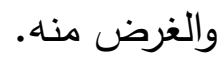

2- لم يتفق الصرفيون على عدد أصول الكلمة، ورأينا أن البصريين يعدُون أصول الكلمة ثلاثة أو أولى أصول

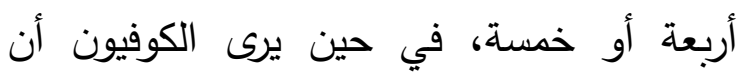
الأصول ثلاثة فقط وما زاد عنها فهو زائد. 3- يترتب على الخلاف في عدد أصول الكلمة اختلاف في طريقة الوزن، فالبصريون يعبرون

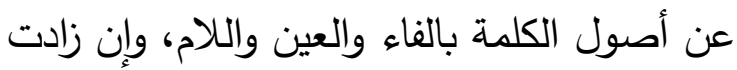

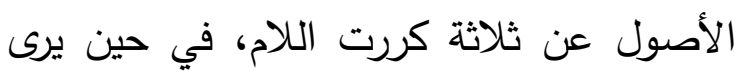
الكوفيون أن الأصول ثلاثة، ثم اختلفوا فيما زاد فيرى بعضهم أن يعبر عن الزائد بلفظه وبعضهم تلاصول

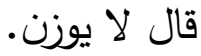
4- لم يتقق البصريون كنلك على طريقة الوزن فيما كان فيه إبدال، فالجمهور يرى ألا يعتد بالإبدال، ويرى الرضي أن المبدل من تاء الافتعال يعبر عنه ئه يالإندال بلفظه، ويجيز الإمام عبد القاهر أن يعبر عن المبدل بمثله فيجيز في وزن قال: فال، وتبعه من المحثين د. تمام حسان، طلبًا للتقريق بين الصيغة الصرفية والميزان الصرفي. 5- يتعامل الصرفيون مع الميزان الصرفي من 
وأهمها: حراسة كتاب الله حتى لا يتهم بأنه شعر، وحراسة نسب الثعر عن مخالطة غيره، وتمييز الأجناس عن بعضها، يقول السخاوي: "فلو كان الثُعر عيل على هذا مجهوًا عندنا غير معروف، وكان أمره بول

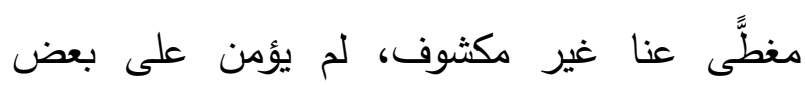
الأغبياء أن يرتاب في القرآن إذا سمع مقالة الكفار فيه،

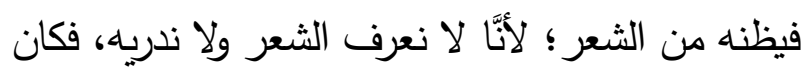

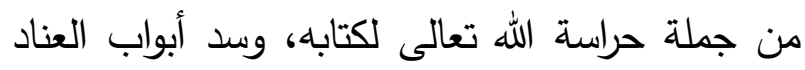
عنه وقطع أسبابه، أن ألهم واضع العروض تعلى طريقًا أفضت إلى حصر أجناس الثعر وأنواعه، وأدت إلى إنى ضبط قوانينه مع تثعبه واتساعه، فتميز حتى صار إنى منظورًا إليه، وتحيز حتى وضعت الأيدي عليه، فليست لفيس فائدة العروض إذن بالحقيرة، ولا منفعته بالتافهة

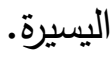

وفائدة أخرى: وهي حراسة نسب الثعب عن مخالطة الدعي وممازجة الغريب الأجنبي. وفائدة ثالثة: وهي أن الثاعر بهذا الميزان يميز الأجناس،

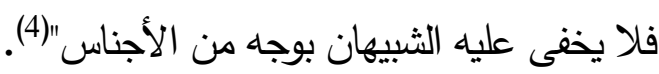

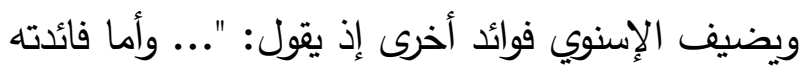

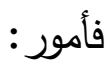

أحدها: معرفة الأوزان الصحيحة من الفاسدة لمن لا

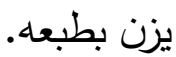
ثانيًا: معرفة ما يجوز مما لم يقبله الطبع السليم كالضرب الثالث من الطويل إذا لم يقبل ما قبله.

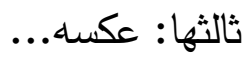

(4) السخاوي، علي، إذهاب العروض بإذهاب الغوض، (28-27).
ولا ينظر للمحذوف سواء حذف نطقًا فقط أو حذف نطقا وكتابة، فالذي يعنيه هو الصوت المنطوق فقط وهل هو متحرك أو ساكن؟ وقد وضع الخليل علم العروض من أجل الوصول سمن

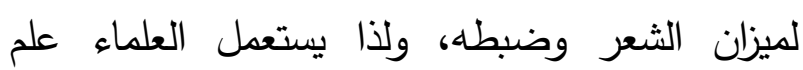
العروض بمعنى ميزان الثعر، يقول الجوهري:

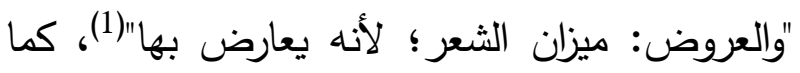
يوضح ذلك ابن دريد بقوله: "ومنه عروض الثعر؛ ليعان لأنه يعارض به الكلام والثعر الموزون"(2). وكذلك عد التبريزي العروض هي ميزان الثعر للحكم

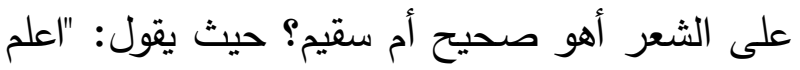
أن العروض ميزان الثعر ، بها يعرف صحيحه من مكسوره... وأصل العروض في اللغة الناحية... فيحتمل أن يكون سمي هذا العلم عروضًا؛ لأنه ناحية من علوم الشعر ، وقيل: يحتمل أن يكون سمي سعري عروضًا؛ لأن الثعر معروض عليه، فما وافقه كان صحيحًا، وما خالفه كان فاسدً"(3). ومن هنا نعلم أن الخليل وضع علم العروض ميزانًا

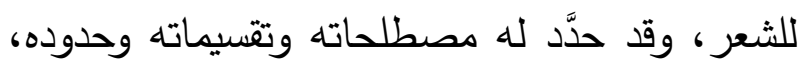
وجعله لمن يريد أن ينسج على منوال شعر العرب مقياسًا، فيعرض شعره عليه فإن وافقهم كان صحيحًا، وإن خالفهم كان سقيمًا.

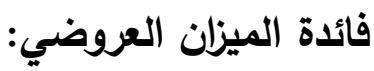
ذكر العلماء الغرض من الميزان العروضي وفائدته،

$$
\begin{aligned}
& \text { (1) الجوهري، أبو نصر، الصحاح ناج اللغة وصحاح العربية، مادة }
\end{aligned}
$$

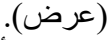

$$
\begin{aligned}
& \text { (2) ابن دريد، أبو بكر، جمهرة اللغة، مادة (رضع). } \\
& \text { (3) التبريزي، الخطيب، الكافي في العروض والقئ القوافي، (17). }
\end{aligned}
$$


قول العروضيين إنها ثمانية فتسامح منهم؛ لأنهج استغنوا عن الثيء بما هو على شكله ووزنه،

استغناء عدد لا استعمال"(5).

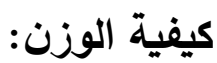

يوضح المحلي كيفية الوزن العروضي بقوله: "فإذا أردت أن تزن بيتًا وتقطعه على مقدار الأجزاء التي لوني لوني يوزن بها، فطريقه أن تنظر في أول البيت، فإن كان

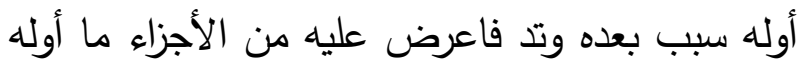
سبب بعده وتد، وإن كان أوله سببان خفيفان أو ثقيل وخفيف بعدهما وتد فاعرض عليه من الأجزاء مثله،

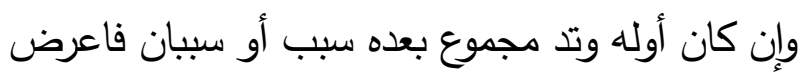
عليه مثله، ولا تزال تمتحن متحركات أول البيت وسواكنه ومتحركات الأجزاء وسواكنها حتى تجد ما لـا يوافق أول البيت، ثم ضع أول حرف في البيت بإزاء

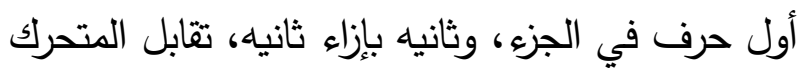
بالمتحرك والساكن بالساكن حتى تستتفد من حروف البيت عدد حروف الجزء، ثم قف عند ذلك، سواء أكان

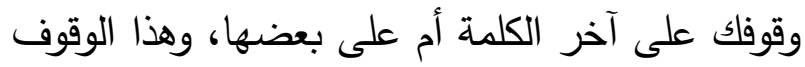

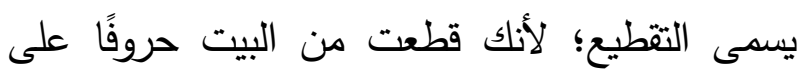

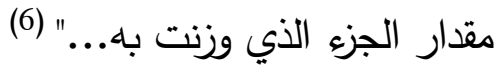
وقد قسم العروضيون تلك التنعيلات إلى مقاطع ووحدات هي السبب والوتد والفاصلة، يقول ابن جني:

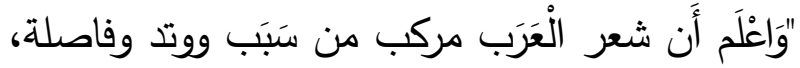
فالسبب على ضَرَبَيْنِ خَفِيف وثَتِيل، فالخفيف: حرف

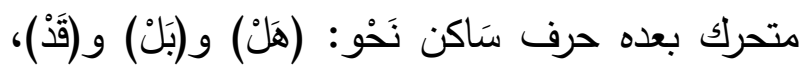
(6) المحلي، محمد، شفاء الغليل في علم الخليل، (65-66).
رابعها: الأمن من تداخل البحور، فقد وقع فيه جماعة من الفحول سماهم ابن القطاع وغيره"(1).

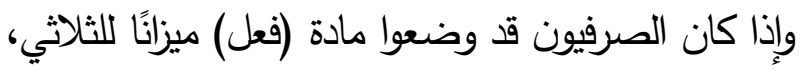
ثم تكرر اللام إن كانت أصلًا، أو يزاد الحرف الزائد بعينه عليها، فقد وضع العروضيون ثماني تفعيلات أساسية

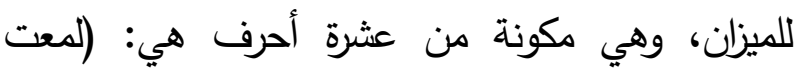
سيوفنا) اشتقوا منها التثعيلات الثماني التي تقوم عليها بحور الشعر، وهي كما وضحها التبريزي بقوله: "والأمثلة التي يُّطَّع بها الثعر ثمانية: اثنان خماسيان وهما: فعولن، فاعلن، وستة سباعية، وهن: مفاعيلن، فاعلاتن، مستقعلن، مفاعلتن، متفاعلن، مفعولات، وما جاء بعد هذا فهو زحاف له أو فرع عليه"(2.). ونلاحظ أن كثيرًا من القدماء يجعلون التفاعيل ثمانية

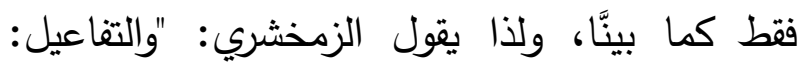
اثنان منها خماسيان، وستة سباعية..."(3). في حين يقسمها المحدثون وبعض القدماء إلى عشر

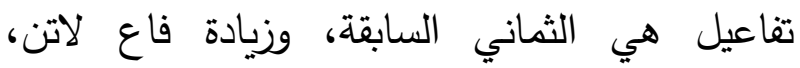
ومستفع لن، كما في قول مصطفى محمود: "وقد كونوا منها عشرة ألفاظ تسمى التفاعيل وهي: فعولن، مفاعيلن، مفاعلتن، فاعلن، فاعلاتن، متفاعلن، مستفعلن، مفعولات، فاع لاتن، مستفع لن" (4).

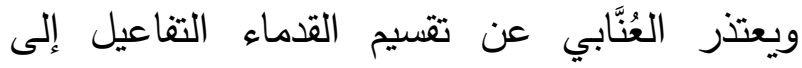
ثمانية فقط بأن هذا تسامح منهم، حيث يقول: "فأما (1) الإسنوي، جمال الدين، نهاية الراغب في شرح عروض ابن الحاجب، (79-78)

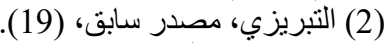

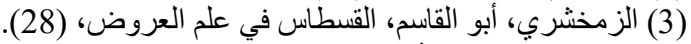
(4) مصطفى، محمود، أهدى سبيل إلى علمي الخليل العروض والقافية القرية 
والثتقيل: حرفان متحركان مَعًا نَخْو: (مَعَ) (لَكَك)، والوتد (مستفعلن) فطم (فعلن). على ضربين: مجموع ومفروق؛ فالمجموع: حرفان وهذه التفعيلات (مستفعلن فاعلن مستفعلن فاعلن)

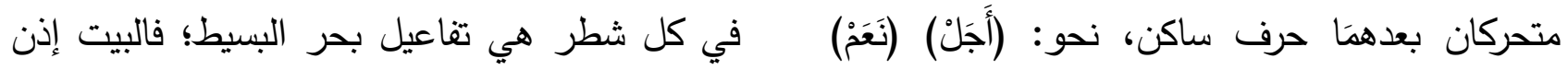
(لَََْ)، والمفروق: حرفان متحركان بينهما حرف ساكن من بحر البسيط.

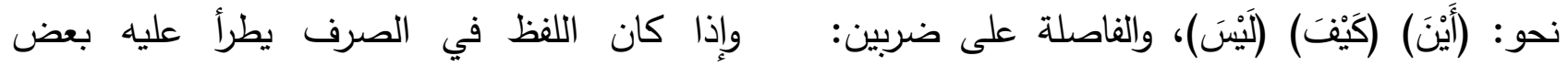
صغيرة وكبيرة، فالصغيرة: ثلاثة أحرف متحركة بعدها التغييرات، بعضها يراعى في الميزان وبعضها لا،

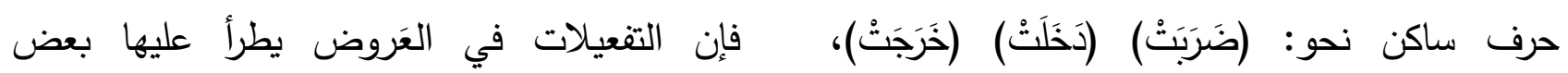
التغييرات أيضًا، تسمى بالزحافات والعلل، فتفعيلة

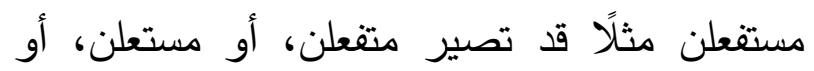
متعلن، وليست كل هذه التغييرات جائزة، بل بعضها يجوز استعماله وبعضها لا، وبعضها يجوز استعماله في بحر معين دون بحر آخر ، ولهذا تفصيلات كثيرة في علم العَروض، ليس غرضنا من البحث التعريف

وجملة التغييرات التي تطرأ على هذه البحور بالزحافات والعلل كما أوضحها العلماء هي أربع وثلاثون عروضًا وثثلاثة وستون ضربًا، كما ذكر ذلك الكاء الزنجاني حيث يقول: "للشعر خمسة عشر بحرًا عند الخليل، وستة عشر عند الأخفش، ولها أربع وثلاثون

$$
\text { عروضًا، وثلاثة وستون ضربًا" (2). }
$$

وقد يلتقي الوزن الصرفي مع الوزن العروضي، وقد

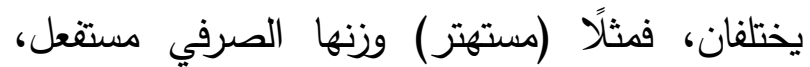
ووزنها العَروضي مستفعلن، وكلمة (مساجد) وزنها الصرفي مفاعل، ووزنها العروضي مفاعلُ، وكلمة (مصابيح) وزنها الصرفي مفاعيل، ووزنها العروضي معني و(فَاذِاًا)، والكبيرة: أربعة أحرف متحركة بعدها حرف ساكن نحو: (ضَرَبَتَا) (دَخَلَتَا) (خَرَجَتَا)" (1). ويمثل لها بعض العروضيين بهذا المثال: "لَّمْ أَرَ

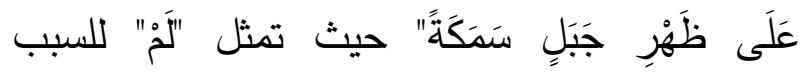

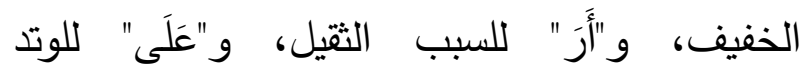
المجموع، و"ظَكْرِ" للوتد المفروق، و"جَبَلٍ" للفاصلة

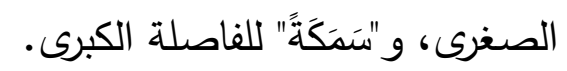
وبحور الثعر العربي (ستة عشر) بحرا مكونة من تلك التفاعيل السابقة، وهي: الطََّيل، والمديد، والبسيط، والوافر ، والكامل، والهزج، وهُ

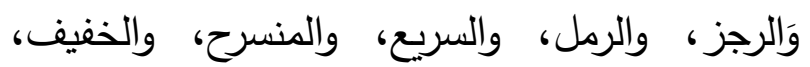

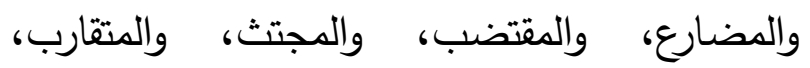
والمتدارك.

وإذا أردنا تطبيق الميزان العروضي على بعض أبيات الثعر نقول مثلا في قول الثاعر:

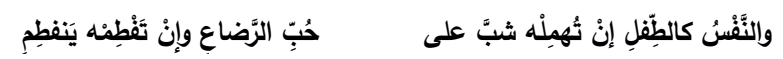
والنفس كالط (مستفعلن) طفل إن (فاعلن) تهمله شب ناعن (مستفعلن) ب على (فعلن) حب الرضا (مستفعلن) ع وإن (فاعلن) تفطمه ين (1) ابن جني، أبو الفتح، كتاب العروض، (61-60). 
الشعر يمنع التقاء الساكنين في غير الضرب فقد همز الثعراء الألف اللينة للخروج من هذه الإشكالية، وقد رصد د. رمضان عبد التواب هذه الظاهرة وبعد أن سجل كثيرا من هذه الألفاظ التي جاءت على هذه الصيغة وذكر شواهدها وأقوال أصحاب المعاجم فيها، قال: "وبعد فهذا أحد آثار الوزن الشعري على أبنية العربية، وهناك الكثير من الآثار الأخرى، فالوزن الثعري هو المسؤول مثلا عن وجود (الكلكال) إلى جانب (الكلكل) بمعنى الصدر ، و(درهام) إلى جانب (درهم)، و(خاتام) إلى جانب (خاتم) وغير ذلك مدا سبق أن أشرنا إلى بعضه في الفصل السابق، وقد روى النحويون بعض الصيخ العربية، التي وردت على غير المألوف فيها والقياس الجاري في أمثالها، ووقفوا أمامها حيارى، وتكلفوا لها التأويل والتخريج، وفاتهم في كل ذلك أن السبب في مخالفتها المألوف، هو استخدامها في الثعر، ذلك الاستخدام الذي حولها عن أصلها لتسجم مع الوزن الثعري، ثم خرجت من الثعر إلى النثر، وشاعت على الألسنة في صورتها الجديدة"(1). وتتساءل الباحثة نادية رزيق قائلة: "ما الفرق بين الميزان الصرفي والميزان العروضي؟ وما أثره في ترقية وتطور وتتمية اللغة العربية فضلً على وظيفته الأساسية وهو وزن الشعر"(2)، ثم تُجيب قائلة: "قد يتبادر لنا الجوابُ أنَّ كنًّ من الميزان الصرفي والعَروضي هما مقياسان يقومان بمعايرة الكلام

(1) عبد التواب، رمضان، فصول في فقه العربية، (224-225).

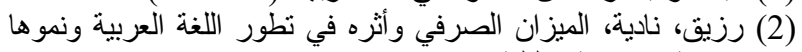
دراسة استقر ائية تحليلية، (56).
كذلك أيضًا، و (كاتب) وزنها الصرفي فاعل، ووزنها العروضي: فاعلن، مع ضرورة الأخذ بالاعتبار ما ذكرناه من أن العروض لا ينظر للكلمة مفردة، وإنما للمقاطع الصوتية، فالكلمة قد يكون لها وزن لكن تركيبها مع أخرى في بيت شعر يجعل لها وزنًا آخر ، انظر مثلًا لكلمة (كاتب) التي قلنا: إن وزنها الصرفي والعروضي فاعل، حين تجيء في بيت مثل هذا:

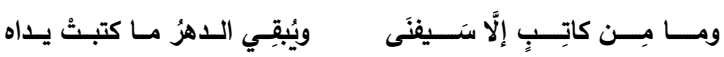
نلاحظ أن تقطيعه عَروضيًّا: وما من كا: (مفاعيلن) تب إلا: (مفاعيلن) سيفنى: (فعولن) فلم تجئ لفظة (كاتب) وحدة مستقلة، وإنما قسمت إلى مقطعين، انضم كل مقطع منها لتفعيلة. وإذا كان الصرفيون لا يزنون الكلمات المبنية بناء لازمًا، ولا الأعجمي، ولا الحروف، فليس في العروض هذا، بل كل ملفوظ منطوق يوزن سواء كان اسمًا أو فعلًا أو حرفًا، فقد لاحظنا كيف خضعت كلمات (ما، من، إلا) للوزن العروضي الموسيقي، في حين أنها صرفيًا لا توزن، ولا يعبر عنها بلفظ الميزان. التكامل بين الوزن العروضي والوزن الصرفي: يُلحظ أن الوزن العَروضي كان له تأثير في الوزن الصرفي، فأدَّى إلى نشأة بعض الصِّيَغ الصرفية، ومن هذا وزن افعأل كاشمأز واخضأل وهذا الوزن وإن نفاه جمهور الصرفيين فقد أثبته أصحاب المعاجم، فوزن اشمأز عند الصرفيين افعلل، غير أن المعجميين يرون أن وزنها افعأل بزيادة الهمزة وأصلها افعالّ، ولأن 
6- الميزان الصرفي يعتني بالمحذوفات، بينما نجد الميزان العروضي يقف عند الحروف المنطوقة كلها. 7- نشاهد الميزان الصرفي يتناول الثعر والنثر على حد سواء، بينما يختص الميزان العروضي بالثعر فقط. 8- تتألف مادة الميزان الصرفي من ثلاثة أحرف هي (ف، ع، ل)، بينما تتكون تفعيلات الميزان العروضي من عشرة أحرف مجموعة في (لمعت (سيوفنا)

9- مما يلاحظ أن أصول الكلمات باعتبار الميزان الصرفي في الأسماء ثلاثية ورباعية وخماسية، وفي الأفعال ثلاثية ورباعية، بينما تصل الأسماء بالزيادة إلى سبعة أحرف، على حين نجد الأفعال تبلغ ستة فقط، ولو نظرنا إلى أصول التفعيلات في الميزان العروضي لوجدنا أن اثتتين خماسية، وستًا سباعية. 10- الميزان الصرفي يختص بوزن الأسماء المتمكنة والأفعال، بينما يزن الميزان العروضي كل ما ينطق به اسمًا أو فعلًا أو حرفًا. 11- يُلحظ التشابه بين الحروف الزائدة عند الصرفيين المجموعة في (سألتمونيها)، وبين حروف تفاعيل الميزان العروضي المجموعة في (لمعت سيوفنا)، فكلاهما عشرة أحرف، ولكن يلفت النظر إلى أن حرفي الهمزة والهاء ليستا من مكونات حروف تفعيلات الميزان العروضي، على حين نجد حرفي الفاء والعين ليستا من حروف الزيادة عند الصرفيين. 12- يُلاحظ التشابه بين تأثر الوزن الصرفي
الموزون، وبالتالي كلاهما أي الميزانان قد ساهما في تطور وتتمية المعجمية اللغوية العربية بشكل واسع، فالأول في مجال النثر، والثاني في مجال الثعر"(1). ومن التكامل بين الميزان العروضي والصرفي أن الثاعر إذا أراد أن يستثمر لفظة ما في شعره سواء حشوًا أو عروضًا أو ضربًا ويحتم عليه الوزن العروضي صيغة معينة، فإنه يجب أن يكون ملمًّا أولًا بالميزان الصرفي وما يستتبعه من اشتقاق الكلمات من بعضها؛ لكي يستثرها بصورة صحيحة ولا يخرج عن أبنية العربية. وقفة تأمل: مما سبق نلاحظ تشابهًا واختلافًا بين الميزان الصرفي والميزان العروضي من نواحِ عدة: 1- الميزان الصرفي يستخدم حروف فعل، وكذا الميزان العروضي يستخدم حروف فعل مع بعض الزيادات. 2- الميزان الصرفي يدخله الحذف والزيادة، وكذا الميزان العروضي يدخله الحذف والزيادة. 3- كلاهما تمثيل للكلمات بميزان اصطلح عليه، فالأول يمثل الكلمة بحروف فعل، والثاني يمثل الحركات والسواكن بالتفعيلات العشر المصطلح عليها. 4- ينظر الميزان الصرفي إلى الكلمة بصفتها كتلة مستقلة، بينما يتعامل معها الميزان العروضي وفق تفاعيله التي تجعلها مقاطع مختلفة. 5- الميزان الصرفي يعتتي بالحروف الأصلية والزائدة، على حين يهتم الميزان العروضي بالحركات والسكنات. 
وإنما فعَلوا هذا من أجل الاختصار بحصر كل الأمثلة التصغيرية في ثلاث صيغ، ويوضح هذا الإستراباذي بقوله: "وقد ينكسر هذا الأصل الممهُّد في أوزان التصغير، إذ قصدوا حَصْرَ جميعها في أقرب لفظ وهو قولهم: أوزان التصغير ثلاثة فُعَيْل، وفُعَيْعِل، وفُعَيْعِيل، ويدخل في فُعَيْعِل دُرَنْهِهُ مع أن

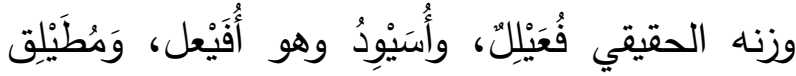
وهو دُفَيْعِل، وَجُجَويْرِب وهو فُوَيْعِل، وحُمَيَيِر وهو فُعَيِّل،

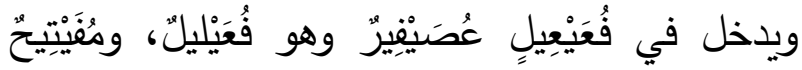
وهو مُفَيْعيل، ونحو ذلك، وإنما كان كذلك؛ لأنهم قصدوا الاختصار بحصر جميع أوزان التصغير فيما يُشترك فيه بحسب الحركات المعينة والسكنات، لا بحسب زيادة الحروف وأصالتها، فإن دُرَنْهًَا مثًَا

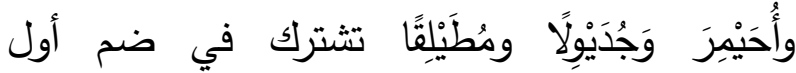
الحروف وفتح ثانيها ومجيء ياء ثالثة وكسر ما بعدها، وإن كانت أوزانه في الحقيقة مختلفةً باعتبار أصالة الحروف وزيادتها، فقالوا لما قصدوا جمعها في لفظ للاختصار : إن وزن الجميع فعيعل، فوزنوها بوزن يكون في الثلاثي دون الرباعي، لكونه أكثر منه، وأقدم بالطبع، ثم قصدوا ألا يأتوا في هذا الوزن الجامع بزيادة إلا من نفس الفاء والعين واللام، إذ لابد للثلاثي -ـإذا كان على هذا الوزن - من زيادة. واختيار بعض حروف "اليوم تنساه" للزيادة دون بعض تحكمٌ، إذ لو قالوا مثلًا أفيعل باعتبار نحو أحيمر، أو مُفَيعل باعتبار نحو مُجَيْلِس، أو فُعَيّل باعتبار نحو حُمَيّر أو غير ذلك كان تحكمًا، فلم
بالحذف أو بحروف الزيادة التي تؤثّر في الميزان الصرفي، وكذا تأثّر الوزن العروضي بالزحافات والعلل سواء كانت بالزيادة أو النقصان أو تغيير الحركات، التي تؤثّر في الميزان العروضي. المبحث الثالث الميزان التصغيري

وضَع العلماء للتصغير ميزانًا خاصَّا به يقوم على تمثيل كل الكلمات المراد تصغيرها بجعلها على أحد القوالب التثلاثثة: فُعَيْل، أو فُعَيْعِل، أو فُعَيْعِيل، كما يقول سيبويـه: "اعلم أنَّ التصغير إنَّما هو في الكلام على ثلاثة أمثلة:

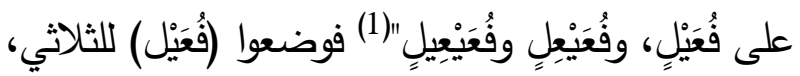
و(فُعَيْعِل) للرباعي، و(فُعَيْعِيل) للخماسي، كما يوضح ذلك ابن جني بقوله: "فمثال فُعَيل لما كان على ثلاثتة أحرف نحو: كَعْب وكُعيب وفَرْخ وفُرَنْخَ، ومثال فُعَيْعِل لما كان على أربعة أحرف نحو: جَعْرِ وجُعَيِفر وجَذْول وجُدَيْوِل، ومثال فُعَيْعِيل لما كان على خمسة أحرف رابعها ألف أو ياء أَو واو زوائد نحو: مِفْتَاح ومُفَنَتِتِح وقنديل وقُنَيْْيل وعصفور وعُصَيِْيِير" (2). ويقول المبرد: "زعم المَازِني عَن الأصمعي أنه قال: قال الْخَليل بن أحمد: وضعت التصغير على ثلاثَّة أبنية على فِلْس وَدِرْهَ ودينار ، ونلك أن كل تصغير لا يخرج

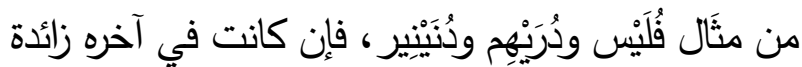
لم يُعتد بها، وصُغِّر على أحد هذه الأمثلة، ثم جيء بالزوائد مسلمة بعد الفراغ من هذا التصغير"(3).

(1) سيبويه، أبو بشر، الكتاب، (415/3).

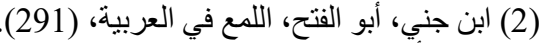
(3) المبرد، أبو العباس، المقتضب، ألخ، (234/2). 
الزمخشري إلى هذا بقوله: "وما خالفهن فلعلة، وذلك ثلاثة أثشياء: محقر أفعال كأجيمال، وما في آخره ألف تأنيث كحبيلى وحميراء، أو ألف ونون مضارعتان كسكيران" (3. .

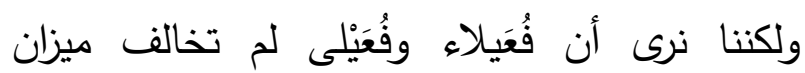

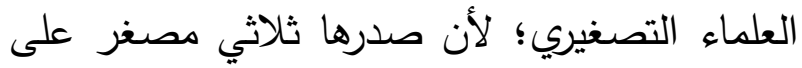

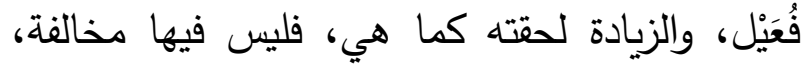
وقد أشار ابن مالك إلى أن هذه الأشياء لا يعتد بهادئ في التصغير، يقول المرادي:

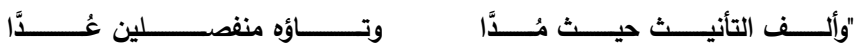

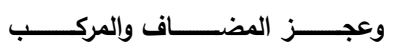

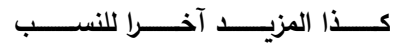

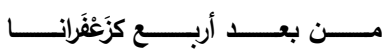

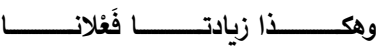

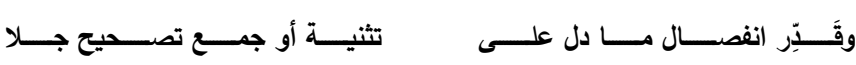
يعني: أنه لا يعتد في التصغير بهذه الأشياء

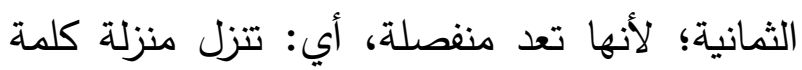

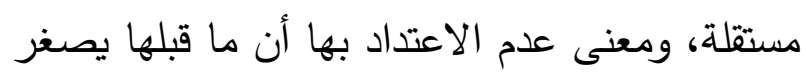

$$
\text { غير متمم بها"(4). }
$$

فلذا لا تعد مخالفة لما وضعه الصرفيون من قوالب

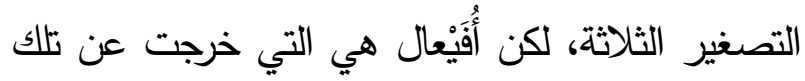
الصيغ، ونتقق مع ما ذكره السيرافي في أنه لو ضم الت

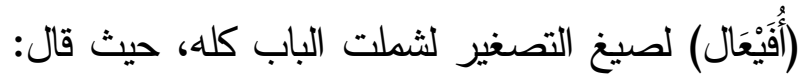

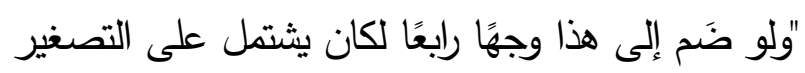

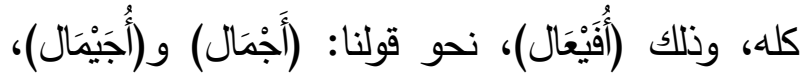

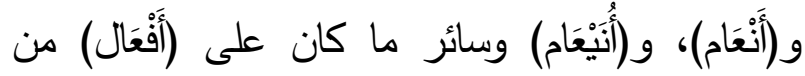

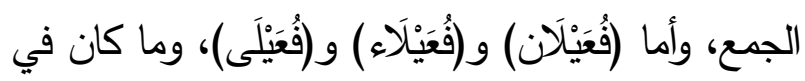
آخره هاء التأنيث، فصدور هذه الأشياء من الثلاثة التي وفي

(3) الزمخشري، أبو القانم، الففل في علم العربية، (194).

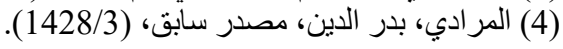

يكن بُدّ من تكرير أحد الأصول، وفي الثلاثي لا

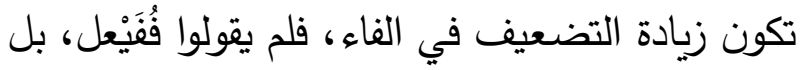
لا تكون إلا في العين كزُرّق أو في اللام كمَهْدَد

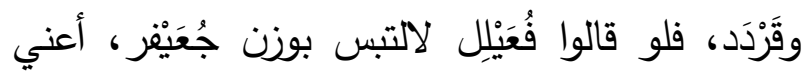
وزن الرباعي المجرد عن الزيادة، وهم قصدوا وزن لون لوني الثلاثي كما ذكرنا، فكرروا العين؛ ليكون الوزن الجامع وزن الثلاثي خاصة، وإن لم يقصدوا الحصر المذكور وزنوا كل مصغر بما يليق به، فقالوا: دُرَيْهِمٌ

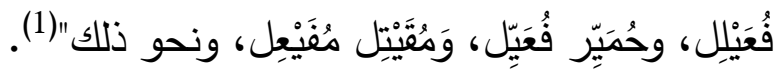

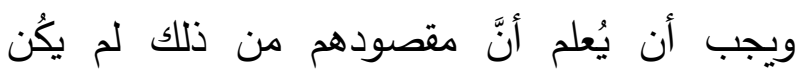
الاختصار وحُدَه، بل كان للرغبة في تقريب المسائل فئل

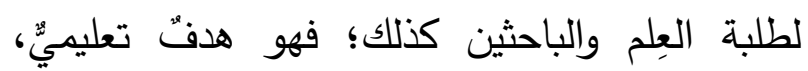
إضافةً إلى الرغبة في الحصر والاختصار ؛ ولهذا قال المرادي جامعًا بين المقصدين: "وزن المصغَّر بهذه الأوزان اصطلاحُ خاص بهذا الباب، اعتُبر فيه لئه مجرَّد اللفظ تقريبًا، وكراهة لتكثير الأبنية، وليس لاهن

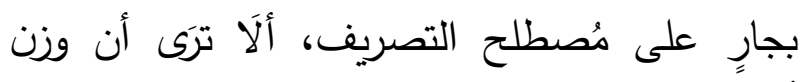
أُحيمد ومُكيرم وسفيرج في التصغير فُعَيعِل، ووزنها

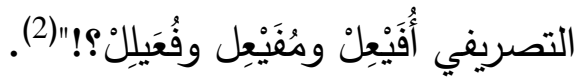
ويَنبغي الإشارة إلى أن هذه المِّيغَ الثَلاث ليستُ شاملة

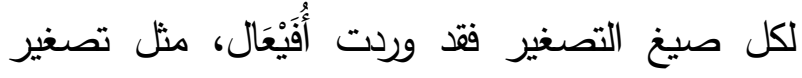

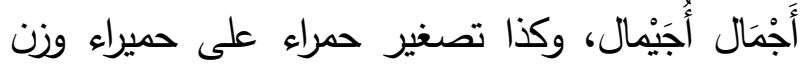
فعيلاء، وتصغير سلمى على سليمى وزن فعيلى، ودماء وتصغير سكران على سكيران وزن فعيلان، ويشير 
والنون وياء النسب، فتصغير سَفَزْجَل: سُفَيْرِج على صيغة فُعَيْعِل، وتصغير مُقَدِّم: مُعَيَدِم على صيغة

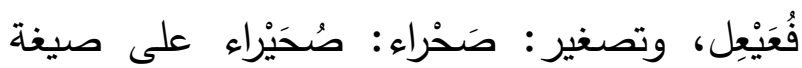

فُعَيْلِ.

وبهذا نرى أن الوزن التصغيري قد يتقق مع الوزن الصرفي وقد لا يتفق؛ فمثال ما اتفق فيه الوزن التصغيري مع الوزن الصرفي: تصغير (رجل) على

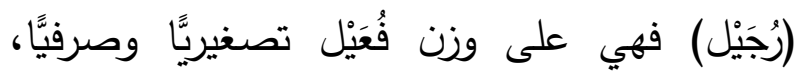

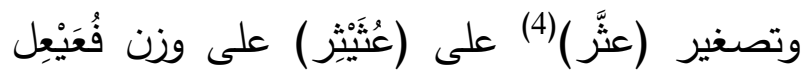
تصغيريًّا وصرفيَّا، وقد يختلفان مثل تصغير (مَجْلِس) على (مُجَيْلِس) على وزنَ فُعَيْعِل تصغيريًّا،

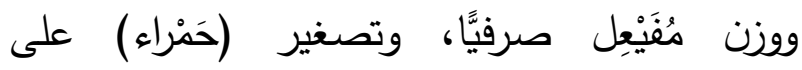

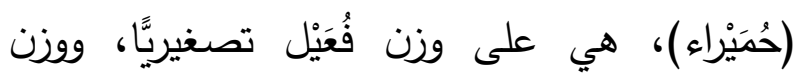
فُعَيْلاء صرفيَّا.

وحينما يعتدُّ الميزان الصرفي بأيّ حذف أو زيادة في الكلمة فتؤثّر الزيادة في الميزان، فإن الميزان التصغيري يتجاهل ثماني زيادات لا يعتد بها كما

سبق ذكرها.

ويتقق الميزان التصغيري مع الصرفي في أنه ليس كل الكلمات خاضعة لقانون التصغير ، مثلما ذكَرْنا في باب الميزان الصرفي أنه ليس كل الكلمات قابلة للوزن الصرفي؛ فالتصغير لا يعتد بالمبنيات إلَّا ما شذَّ مِن بعضها كتصغيرهم الذي باللذيا، وتصغير بالِيرير التي باللتيا، كذلك التصغير لا يدخل الفعل، في حين

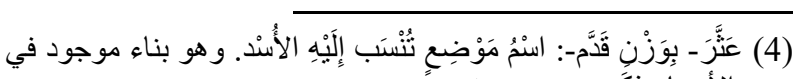

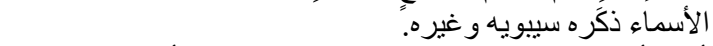
ابن الأثير ، أبو السعادات، النهاية في غريب الحديث و الأثر ، (3/ 183).
ذكرها، وإنما النقص في (أُفَيْعَال)"(1). لكن الثاطبي لا يتفق مع السيرافي فيما ذهب إليه ويرى أن (أُفَيْعال) راجع إلى (فُعَيْعِيل) لكن لم يكسر فيرِي ما بعد ياء التصغير؛ لعلة فوات الجمع لو كسر ، إذ يقول: "(وكذلك (أُفَيعال) هو راجع إلى (فُعَيعِيل) لكنه لم يُكسر لعلةٍ تذكر بعد إن شاء الله) فليس قول السيرافي فيها بموافق لمذاهب النحوين" (2). في حين يرَى ابنُ يَعيش أن سيبويـه لم يذكر الوزن

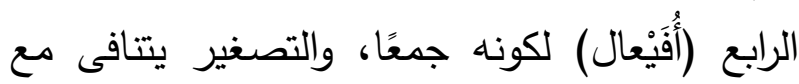
الجمع، إذ هو تقليل والجمع تكثير ، يقول ابن يعيش: "وإنما لم يذكر سيبويه هذا البناء؛ لأنه جمعُ، والتصغيرُ ليس قعيدًا في الجمع، وذلك من قِبَل أن المراد من الجمع الدلالة على الكثرة، والتصغير تقليل، فكان بينهما تَنافٍ. فلذلك لم يذكره إذ كان الدليل يأباه. والذي حسّنه ههنا أنه من أبنية القلّة"(3). وإذا أريد تصغير اسم فإنه يضم أوله ويغتح ثانيه وتزاد ياء ساكنة ثالثة، حتى يصير الاسم على مثال

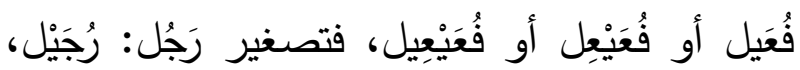
وتصغير ، جَغْفَر جُعَيْغِر ، وتصغير مِفْتاح: مُفَنْتِح.ح. وإذا كان في الاسم زوائد تخل بصيخ التصغير فإنك تحذفها حتى يصير الاسم على أحد الأمثلة الثلاثة المذكورة، مع ملاحظة أنه ليس كل زيادة تحذف، فبعض الزيادات الطرفية لا تحذف كألف التأنيث المقصورة والممدودة، وتاء التأنيث وزيادة الألف لتف

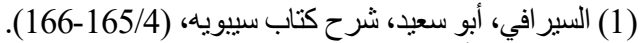
(2) الثاطبي، أبو إسحاق، المقاصد الثافية في شرح الخلاصة الكافية، (275/7)

(3) ابن يعيش، أبو البقاء، شرح المفصل، (398/3). 
أن الفعل يوزن صرفيًا، وكذلك فإن التصغير ل ل لكن ألفاظ الميزان التصغيري وألفاظ الميزان يجوز في المعظم شرعًا، يقول ناظر الجيش: "ثم العروضي لا يمكن أن تتفق، إذ للميزان التصغيري

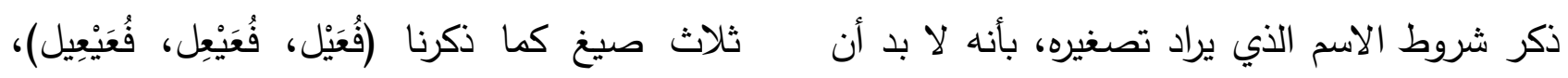

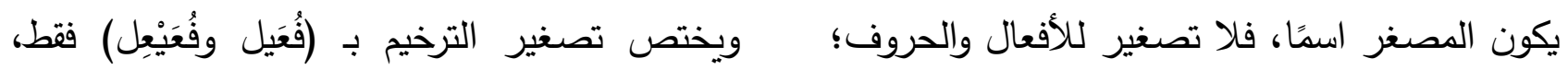

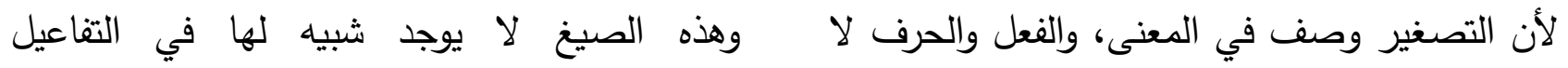
يوصفان، ولا بد أن يكون المصغر غير متوغل في

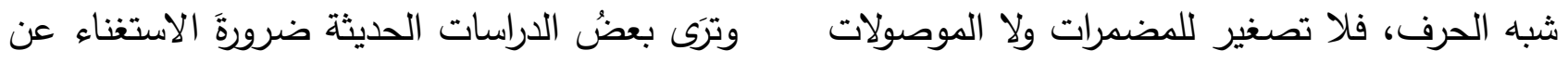

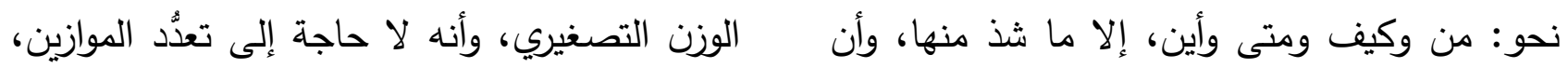

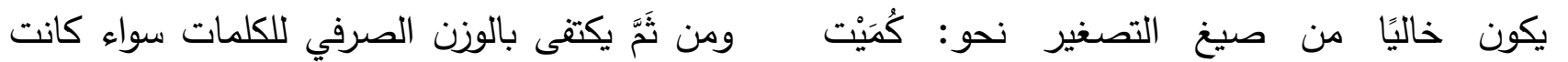
وكُعَيْ...، وكذا مثل شبه صيغة التصغير كقليل؛ مصغرة أو غير مصغرة، كما تقول د. سليمة جبار:

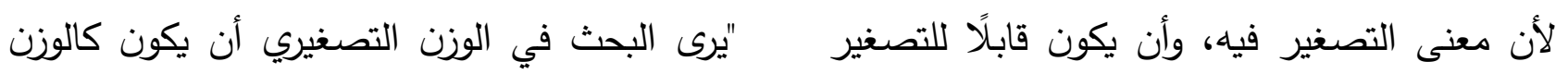

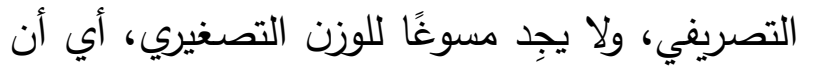

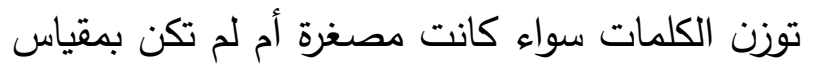

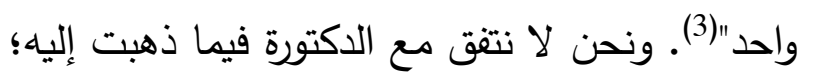

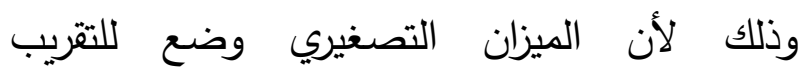
والاختصار ولم يوضع لتبيين الأصول من الزوائد،

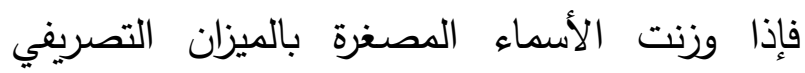
ستكون لاينا أوزان كثيرة جدَّا منها أُفَيَعل ومُفَفيعل

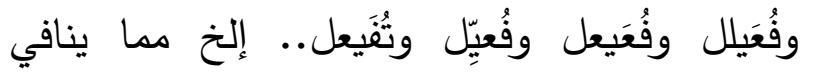
الاختصار، لكن في الميزان الصرفي نحن بحاجة

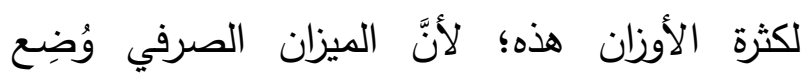
لاستقراء كل أبنية العربية، وبيان الأصلي من الزائد في الكلمة، وصيخ الميزان التصغيري شمِلت كل

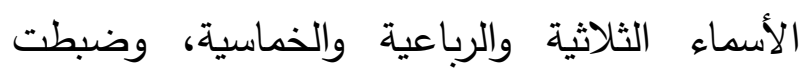
الحركات والسكنات، وهو ما يَسعَى إليه الميزان وليس وليس وصنيه بأن لا ينافيه، فلا يصغر مثل كبير وجسيم، وكذلك لكان

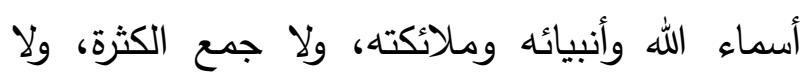
أسماء الثهور كالمرم والأسبوع كالسبت والأحد، ولاء الأسماء العاملة عمل الفعل، وكذلك حسب، وأحد، وكل، وبعض، وأي، وغير ذلك مما ينافي معنى التصغير" (1). - (1) ومن اللافت للانتباه أنَّ الميزان التصغيري يتثابه مع

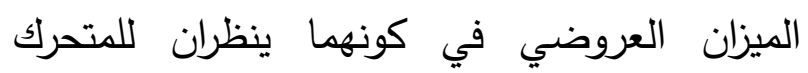
والساكن ولا يراعيان الأصلي من الزائد، في حين أن لنئن

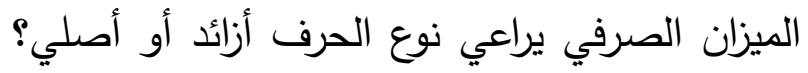
يقول ناظر الجيش: " وينظر فيه مجرد الهيئة اللفظية من حيث الحركات والسكنات وعدد الحروف، بقطع

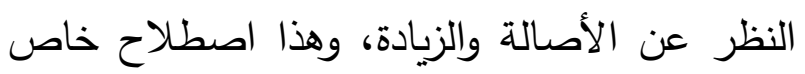
بهذا الباب فلا تغيير فيه"(2). 
4- الميزان التصغيري يعت ببعض المحذوفات وبالأخص في الثلاثي الذي حذف أحد أصوله(4)، بينما الصرفي يعتد بها كلها، وأما العروضي فيقتصر على المنطوق منها، ولو نظرنا إلى المزيدات الطرفية لوجدنا أن الميزان التصغيري لا يعتد بثمان منها، على حين نجد العروضي يتعامل مع الحروف على السواء شريطة أن تكون منطوقة، بينما يتأثر الميزان الصرفي بالحروف المزيدة. 5- الميزان الصرفي يُعنى بالحروف المبدلة، وكذا الميزان التصغيري، وأما العَروضي فلا. 6- الميزان الصرفي والتصغيري كلاهما ينضويان تحت علم الصرف، الذي يختص بالكلمة المفردة شعرًا أو نثرًا، وأما العروضي فيتبع علم العروض لع الذي ينصب اهتمامه على الثعر فقط. 7- نلحظ تثابهًا بين الموازين الثلاثة في اختصاص كل صيغة بنوع، فصيغ الميزان التصغيري الثخلاث مختصة بأحد أصول الأسماء الثلاثة ف(فُعَيْل)

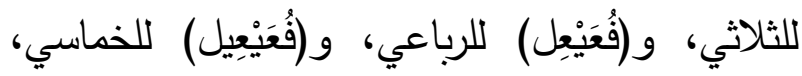
وصيغ الميزان الصرفي أيضًا موضوعة للثلاثي مجرده ومزيده وللرباعي مجرده ومزيده وللخماسي مجرده ومزيده، ونجد صيخ الميزان العروضي وضعت لكل بحر صيغًا معينة من البحور الستة عشر، مع تثابه البحور في بعض الصيغ كدخول فعولن في الطويل وفي المتقارب، ودخول مفاعيلن في الهزج والمضارع. 8- يشترك الميزانان العروضي والتصغيري في أن
تبينَ الزائد من الأصلي في الاسم الأُصغَّر. نظرات فيما سبَق : 1- مادة الميزان الصرفي مكونة من ثلاثة أحرف هي: (ف، ع، ل) وكذلك الميزان التصغيري فأوزانه الأصول ثلاثثة (فُعَيْل، فُعَيْعِل، فُعَيْعِيل)، وحروف صيغه الثَلاث كما مر مكونة من أحرف الميزان الصرفي مع زيادة (الياء) عليها، بينما تتألف تفعيلات الميزان العروضي من عشرة أحرف مجموعة في (لمعت سيوفنا)، ونلحظ أن حروف مادة الميزان الصرفي وكذا صيغ الميزان التصغيري ضمن هذه الأحرف العشرة. 2- لميزان التصغيري ثلاث صيغ لقلته في الكلام؛ ولأن أبرز معانيه القلة، ولأنهم قصدوا الاختصار أيضًا بحصر جميع أوزان التصغير فيما يشترك فيه بحسب الحركات والسكنات لا بسبب زيادة الحروف وأصالتها (1)، وحين سئل الخليل لم بنيت المصغر على هذه الأمثلة؟ فقال: وجدت معاملة الناس على ودرهم ودينار."(2)، وللعروضي عشر تفعيلات، وأما الصرفي فكثيرة جدًا، فأوزان المزيد فقط تبلغ ثلاثمائة وثمانية على ما نقله سيبويه بخلاف ما استدركه بعضهم، فضلًا عن

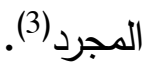
3- الميزان التصغيري يتناول الأسماء وبشروط أيضًا، بينما الصرفي يتسع قليلً ليشمل الأسماء المتمكنة والأفعال، على حين نجد العروضي لا يفرق بين أنواع الكلمة الثلاثة.

(1) الإستر اباذي، مصدر سابق، (14/1). (2) المر ادي، بدر الدين، مصدر سابق، (14/1/1421/3). (3) الحملاوي، أحمد، شذا العرف في فن الصرف، (109)، (121). 
البحث، وإنما ينظر هذا في كتب اللغة المعنية بها، ولكن أردت استعراض طريقة الموازين عند علماء اللغة من أجل الوصول لنظرة متكاملة للموازين

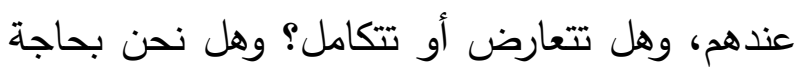
إلى موازين جديدة أو لا؟ والذي يتضح لي أننا لا نحتاج إلى إضافة موازين جديدة؛ فالميزان الصرفي شمِل كل أبنية العربية، وأمَّا

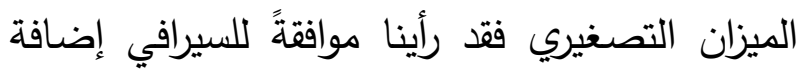

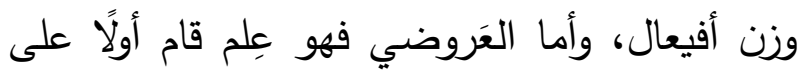
استقراء بحور الثعر العربي ولا يحتاج إلى إضافة

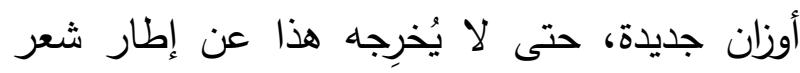
العرب، وإليك ما توصل إليه، البحث من نتائج

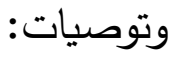

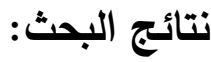

استعرض البحث الميزان الصرفي والعَروضي والتصغيري، وتوصل إلى نتائج عدة؛ منها:

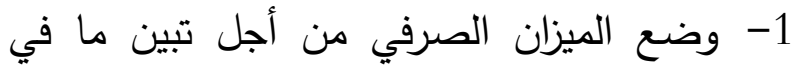
الكلمة من حروف أصلية أو زائدة، أو حذف، وقد لتين نجح في هذا، لكن تكتنفه بعض الصعوبات؛ لأن الكثير من الدارسين لا يعلمون ما جرى في الكلمة من إعلال وإبدال فيلتبس عليهم الأصلي بالزائد، ورأينا أن الجرجاني أجاز أن يقال في وزن قال: فال، الهال وهي تحل مشكلة كبيرةً لاى الدارسين، لكنها تُنافي الغرضَ من الميزان؛ إذ بهذا لا يُعرَف هل الألف لهِي منقلبة عن أصل أو زائدة؟ ولذا نرى أنَّ الميزان المشتهر عند جمهور البصريين يؤديّي الغرضَ منه.
واضعهما هو الخليل بن أحدد، بينما اختلف في واضع الميزان الصرفي بناء على اختلافهم في واضع

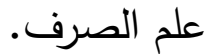
9- يظهر بجلاء في ضوء صيخ الموازين الثلاثة بأن المراد بها الحصر والاختصار والتقريب. 10-اتفاق الميزانين العروضي والتصغيري في في عنايتهما بالحركات والسكنات وعدد الحروف، بينما يهتم الميزان الصرفي أكثر بمعرفة الحروف الأصلية والزائدة، وإن كانت الحركات والسكنات ضمن مجال

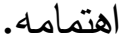
11- لا يخرج عن الميزان الصرفي والعروضي ما كان داخلًا في نطاقهما، على حين نشاهد الميزان التصغيري قد أضيف له صيغة رابعة عند بعض العلماء هي: (أُفَيْعال)؛ لكي يحيط بما يندرج في إطاره. 12-قد يتقق الميزان الصرفي والتصغيري في وزن بعض الكلمات وقد يختلفان وهو الأكثر، بينما ينفرد

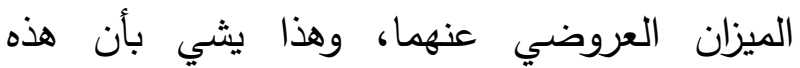
الموازين وإن اتفقت في بعض المواضع إلا أن لكل واحد منها طريقته وغايته، وعلى هذا فهي متكاملة من جانب متعارضة من آخر تعارضًا يؤدي إلى أن تكون متوازية غير متداخلة. الخاتمة

استعرضتُ في هذا البحث الموازينَ عند علماء اللغة، وعرَضت لطريقة الميزان عند الصرفيين، وعند العروضيين، وفي باب التصغير، ولم أتطرَّق لتفصيلات تلك الأبواب؛ إذ ليس هذا غرضي من 
بسبب حروف الزيادة، في حين لا تلتقي صيغة الميزان التصغيري مع الميزان العروضي أبدًا.

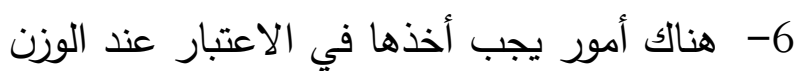

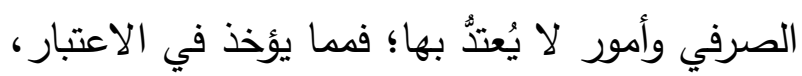
القلب المكاني والحذف والتضعيف، ولا يعتد بالإعلال والإبدال والإدغام، بينما لا يهتم الميزان التصغيري بالحذف إلا في الثلاثي، وأما الميزان العروضي فلا يعتني بالإبدال ولا الإدغام ولا الحذف التف

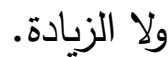
توصيات البحث:

1- ما زال الميزان الصرفي تكتنفه صعوبات كثيرة لارتباطه بأبواب صرفية أخرى كالإعلال وحروف لإن الفيرن الزيادة، ولا يتقن الميزان الصرفي إلا من كان مُلمَّا بالأبواب الأخرى، ويحتاج هذا الباب إلى مزيد من إلى هن هن

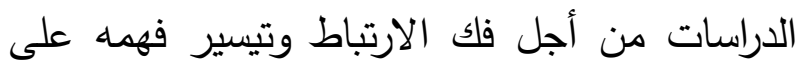

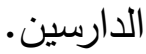

2- يحتاج البحث لدراسات بينية بين علمي العروض والصرف من أجل توضيح العلاقة بينهما في الميزان مثلًا، وفي الحروف المحذوفة والمدغمة. 3- بعض الآراء في الميزان الصرفي شاذة وتزيد من صعوبة فَهم الباب؛ لذا يُوصَى بالاقتصار على لـى المشهور من مذاهب الصرفيين، وجعل تلك الآراء المخالفة خاصة للمتخصصين وراغبي التوسع. 4- الاهتمام بتدريس الموزاين الثلاثة الصرفي والعروضي والتصغيري خلال مراحل التعليم المختلفة

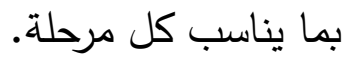

2- سعَى الميزان العَروضي إلى ضبط إيقاع الثعر

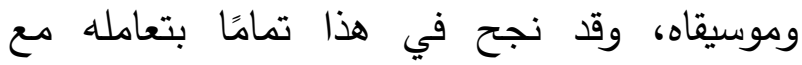

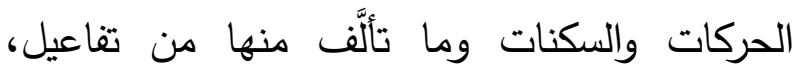
وفرعياتها، لكن تواجه دارس العروض مشكلة كثرة

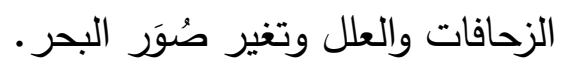
3- الميزان التصغيري وُضِع لاختصار كل صور

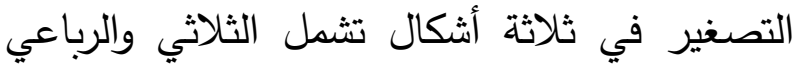
والخماسي، سوى ما شذَّ، ونتفق مع السيرافي في أنه تلهيت لو أُضيف لصيغ التصغير (أفيعال) لكان شاملاً لكل الصيغ التصغيرية. 4- لا يمكن أن يوجد تعارض بين الموازين الثلاثة، وإن وجد فهو تعارض مؤد إلى تكاملها في صورة متوازية، وذلك لأن كل ميزان وضع من أجل تحقيق غرض معين خاص باه، فلن نقيس الثعر بميزان الصرف، ولن نزن الكلمة بميزان العروض، وما دام كل بهن ميزان حقق الغرض المراد منه فهي -إذن- متكاملة متوازية تَسير جنبًا إلى جنب، وكل منها يخدم غرضًا

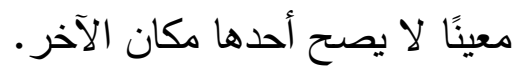
5- يتكامل الميزان العروضي مع الميزان الصرفي ويحتاج كل منهما إلى الآخَرَ نظرًا إلى أنَّ قانون

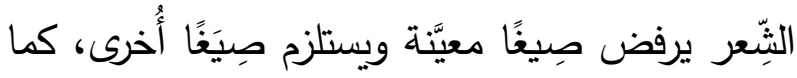
أنَّهما قد يلتقيان في بعض الألفاظ وقد يختلفان، كما هو الحال بيْن الميزان الصرفي والميزان التصغيري؛ فيلتقي الميزان الصرفي والميزان التصغيري في بعض

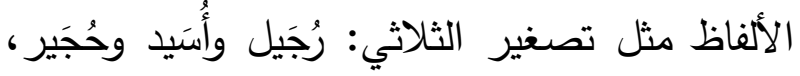
على فُعَيْل صرفيًّا وتصغيريًّا، ويختلفان في كثير 
5- تدرج أغلب كتب النحاة التصغير ضمن نطاق التصغير على أنها أربع صيغ لا ثلاث.

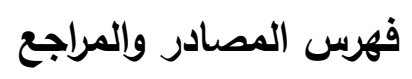
* ابن الأثير، أبو السعادات، 1399هـ/ 1979م.

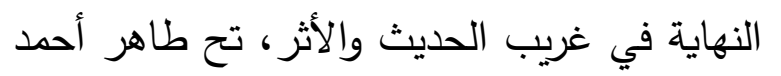

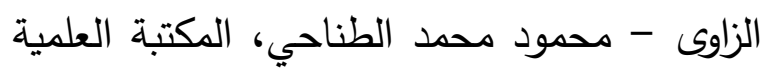

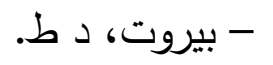

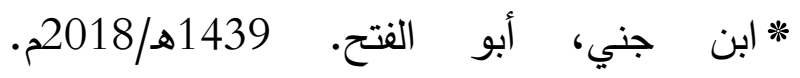

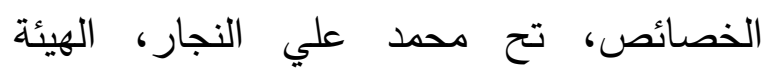
المصرية العامة للكتاب، القاهرة، ط6. * ابن جني، أبو الفتح. 1373هـ/1954م. المنصف

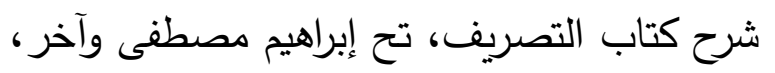
دار إحياء التراث القديم، القاهرة، ط1 التصرين

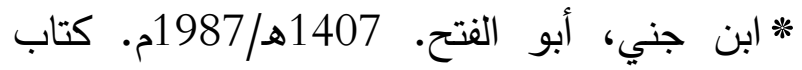
العروض، تح د. أحمد الهيب، دار القلم، الكويت لتون

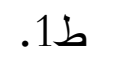
* ابن جني، أبو الفتح. 1976م. اللمع في العربية، تح د. حسين شرف، عالم الكتب، القاهرة، ط1. * ابن دريد، أبو بكر . 1407هـ/1987م. جمهرة اللغة، دابل تح رمزي بعلبكي، دار العلم للملايين، بيروت، ط1.

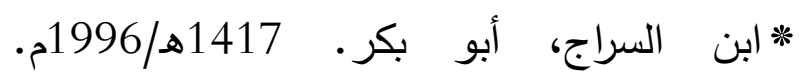
الأصول في النحو، تح عبد الحسين الفتلي، مؤسسة الرسالة، بيروت، ط3.

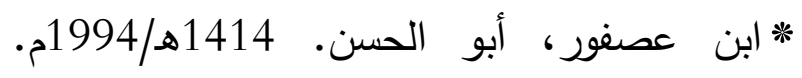
المتع الكبير في التصريف، تح د. فخر الدين قباوة، مكتبة لبنان، بيروت، ط8. * ابن عقيل، بهاء الدين. 1400هـ/1980م. لينان. دراستها، ويرى الباحث أن ينفصل باب التصغير عن

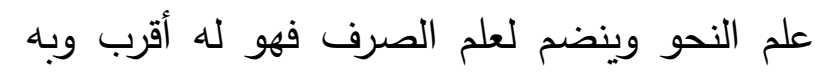

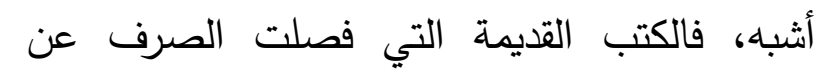
النحو لم يذكر فيها باب التصغير، فلم يفعل هذا

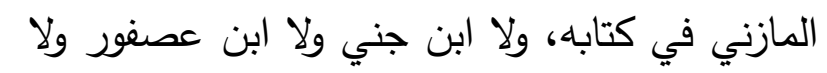

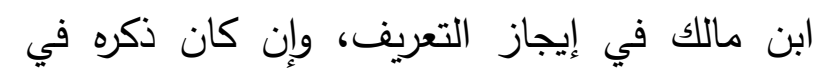

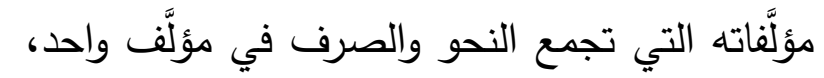
غير أن ابن الحاجب ذكر التصغير في الثافية، وهو ما نُوصي بالسير على منواله. 6- نوصي بأن يشتمل درس الميزان على الآراء

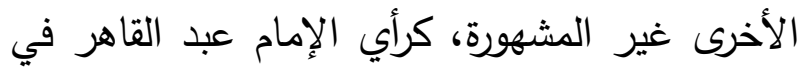
الميزان؛ فهو يحقق هذا الغرَض ويزن الشكل الحالي للكلمة، ويكون هذا متوازيًا مع الميزان الأصلي عند لئد

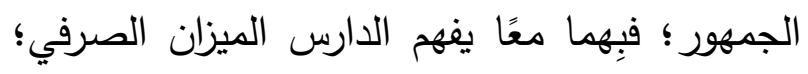
لأن الميزان الصرفي لم يُوضَع لأجل تصوير الكلمة

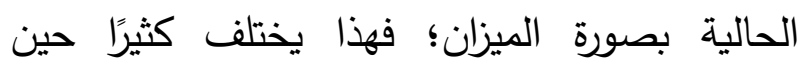
يحدث إبدال وإعلال، وإنما وضع من أجل تبين

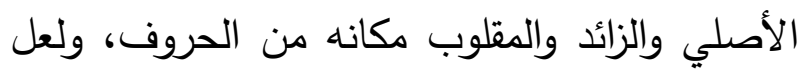

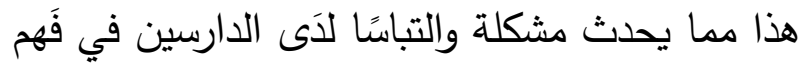

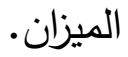
7- دأبت كتب الصرف على الاقتصار على ذكر الصيخ الثلاث التي وضعها الخليل للميزان التصغيري، وتجاهلت قول السيرافي في إضافة (أُفَيْعال)، ويَرى الباحث أنَّ رأي السيرافي وجيه ويسهل الدرس ويحل إثكالية مهمة، وأن تدرس صيغ ليغ لئي 
المساعد على تسهيل الفوائد، تح د. محمد كامل القاهرة، ط1. * التبريزي، الخطيب. 1415هـ/1994م. الكافي في الفره، بركات، دار الفكر، دمشق، دار المدني، جدة، العروض والقوافي، تح الحساني عبد الله،، مكتبة

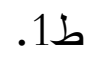
الخانجي، القاهرة، ط3. * الثمانيني، عمر. 1419هـ-1999م. شرح التصريف، تح د. إبراهيم البعيمي، مكتبة الرشد، الرياض، ط1. * ابن مالك، محمد. 1422هـ/2002م. إيجاز التعريف في علم التصريف، تح محمد المهدي سالم، عمادة البحث العلمي، المدينة المنورة، لعرئ

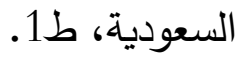

* جبار ، سليمة. 1434هـ/2013م. الوزنان التصريفي والتصغيري في اللغة العربية رؤية في تيسير الترنية الصرف العربي، مجلة آداب ذي قار ، العدد العاشر . * الجرجاني، عبدالقاهر • 1428هـ/2007م.

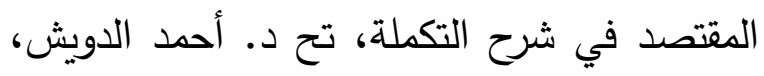

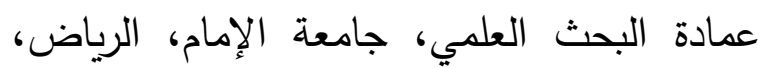
b 1 b * الجوهري، أبو نصر • 1407هـ/1987م. الصحاح تاج اللغة وصحاح العربية، تح أحمد عطار ، ط4.

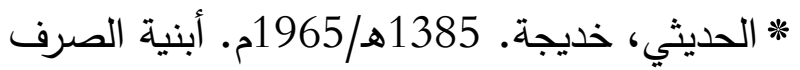
في كتاب سيبوياه، مكتبة النهضة، بغداد، ط1، * حسان، تمام. 1421هـ/2001م. اللغة العربية معناها ومبناها، دار الثقافة، الدار البيضاء.

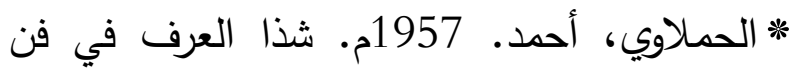
الصرف، دار الكبار ، الرياض، ط12. * الخطيب، عبد اللطيف. 1424هـ/2003م. المستقصى في علم التصريف، مكتبة دار العروبة، الكويت، ط1 *رزيق، نادية. 1437هـ/2016م. الميزان الصرفي وأثره في تطور اللغة العربية ونموها دراسة استقرائية تحليلية، * ابن يعيش، أبو البقاء. 1422هـ/2001م. شرح المفصل، تح إميل يعقوب، دار الكتب العلمية،

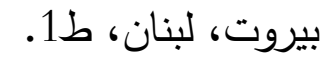
* ابن يعيش، أبو البقاء. 1438هـ/2017م. شرح

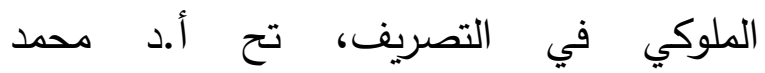
المحرصاوي، دار الكتب والوثائق القومية، القاهرة، * الأزهري، خالد. 1418هـ/1997م. التصريح بمضمون التوضيح، تح د. عبد الفتاح بحيري، الزهراء للإعلام العربي ط1.

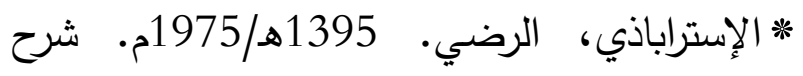
شافية ابن الحاجب، تح محمد الحسن وآخرين، دار الكتب العلمية، بيروت، لبنان.

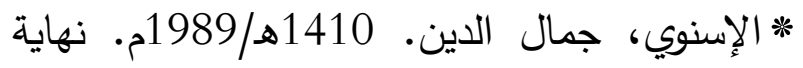
الراغب في شرح عروض ابن الحاجب، تح د. شعبان صلاح، دار الجيل، بيروت، ط1 سئ ابن

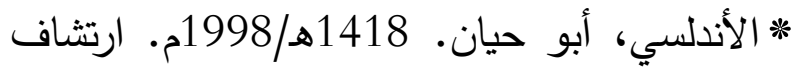
الضرب من لسان العرب، تح د. رجب عثمان،

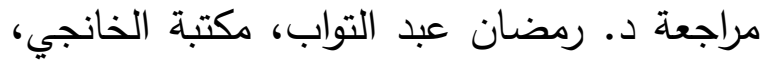


* العكبري، أبو البقاء. 1416هـ/1995م. اللباب في علل البناء والإعراب، تح د. عبد الإله نبهان، دار البعار

$$
\text { الفكر ، دمشق، ط } 1 .
$$

* عبد التواب، رمضان. 1420هـ/1999م. فصول

في فقه العربية، مكتبة الخانجي، القاهرة، ط6. * العُنّابي، أبو العباس. 1436هـ/2015م. نزهة الأبصار في أوزان الأشعار، تح حسام الدين مصطفى، منشورات شبكة الألوكة:

https: //www.alukah.net/library/0/90696/

* عبد الدايم، أحمد. 2011م. الميزان الصرفي نظرة جديدة. تاريخ الإضافة: 2011/8/21م. نشر

https:

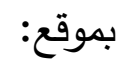

//www.alukah.net/literature_language/0/340 95/ * المبرد، أبو العباس. المقتضب. 1415هـ/1994م. تح عبد الخالق عضيمة، وزارة الأوقاف، لجنة لهابل إحياء التراث الإسلامي، القاهرة، ط3. * المحلي، محمد. 1411هـ/1991م. شفاء الغليل في علم الخليل، تح د. شعبان صلاح، دار

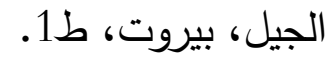
* المرادي، بدر الدين. 1422هـ/2001م. توضيح المقاصد والمسالك بشرح ألفية ابن مالك،، تح أ.د عبد الرحمن سليمان، دار الفكر العربي، القاهرة، . 1 b * مصطفى، محمود. 1426هـ/2005م. أهدى سبيل إلى علمي الخليل العروض والقافية، تح عمر الطباع، مؤسسة الكتب الثقافية، بيروت، لبنان.
مذكرة تخرج للحصول على شهادة ماستر في اللغة والأبب، جامعة الثهيد حمة لخضر ، الجزائر. * الزمخشري، أبو القاسم. 1410هـ/1989م. القسطاس في علم العروض، تح د. فخر الدين قباوة، مكتبة المعارف، بيروت، ط2.

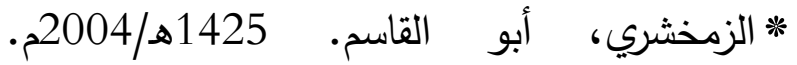
المفصل في علم العربية، تح د. فخر قدارة، دار

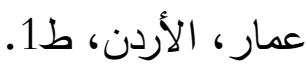
* الزنجاني، عبدالوهاب. 1411هـ/1991م. كتاب معيار النظار في علوم الأشعار، تح د. محمد الخفاجي، دار المعارف، القاهرة، ط1.

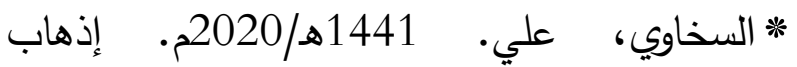
العروض بإذهاب الغوض، تح حسام الدين مصطفى، معهد المخطوطات العربية. ط1. * سييويه، أبو بشر، 1408هـ/1988م. الكتاب، تح عبد السلام هارون، مكتبة الخانجي، القاهرة، ط3.

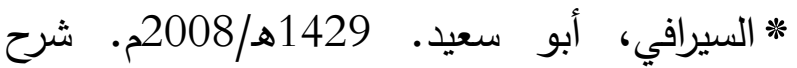
كتاب سيبويه، تح أحمد مهدلي وآخر ، دار الكتب العلمية، بيروت، لبنان، ط1. * السيوطي، جلال الدين. 1418هـ-1998م. همع لهع الهوامع في شرح جمع الجوامع، تح أحمد شمس جله الدين، دار الكتب العلمية، بيروت، لبنان، ط1. * الثاطبي، أبو إسحاق. 1428هـ/2007م. المقاصد الثافية في شرح الخلاصة الكافية، تح أ.د محمد الثد

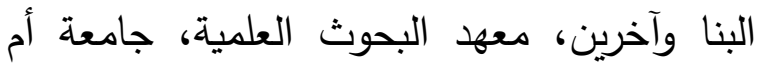

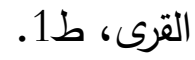




$$
\text { عبيد بن أحمد بن عبيد المالكي }
$$

* ناظر الجيش، محمد. 1428هـ. شرح التسهيل دراسة وتح أ. د علي فاخر وآخرين، دار السلام، المسمى (اتمهيد القواعد بشرح تسهيل الفوائده، القاهرة، ط1. 


\title{
Integration or Contradiction in Scales of Arabic Language.
}

\author{
Dr. Obaid bin Ahmed bin Obaid Al-Maliki \\ Assistant Professor of Grammar \\ Al-Baha University \\ Arabic language Department \\ Art and Human Science Facility
}

\begin{abstract}
Scale, metrical Scale, and diminutive Scale.

The researcher endeavored to review the Arabic scales and answer the main question; is relation between phonic, metrical and diminutive scales Integral or contradictory?

The researcher used the descriptive and analytical method, and reached to that: in spite of Contradiction it was found in some cases because of the differences in three fields ,particularly in their subjects and purposes, the scales are Integral In the most of its procedures.

Key words: Scale- Arabic- Phonetic- Meter- Diminutive- Integration- Contradiction.
\end{abstract}

